\title{
Terrestrial isopods (Isopoda: Oniscidea) of the Botanical Garden of Cartagena "Guillermo Piñeres", Colombia, with the description of three new species
}

\author{
Moкриџы (Isopoda: Oniscidea) ботанического сада Картахены \\ «Гияьермо Пиньерес», Колумбия, с описанием трех новых видов
}

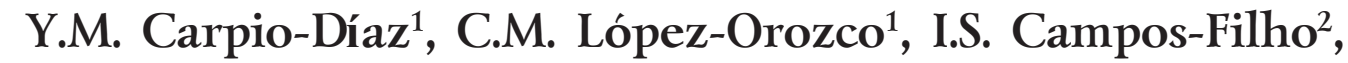 \\ G.R. Navas S. ${ }^{3}$ \\ Е.М. Карпио-Аиас ${ }^{1}$, К.М. Аопес-Орозко ${ }^{1}$, И.С. Кампос-Фицьо \\ Г.P. Навас C. ${ }^{3}$
}

\begin{abstract}
${ }^{1}$ Grupo de Investigación en Biología Descriptiva y Aplicada, Universidad de Cartagena, Programa de Biología, Campus San Pablo, Barrio Zaragocilla, Cartagena de Indias, Colombia. E-mail: ycarpiod@unicartagena.edu.co, clopezo1@unicartagena.edu.co

${ }^{2}$ Programa de Pós-Graduação em Recursos Naturais, Universidade Federal de Campina Grande, Campina Grande, Paraíba, Brazil. E-mail: ivanklin.filho@gmail.com

${ }^{3}$ Grupo de Investigación Hidrobiología, Universidad de Cartagena, Programa de Biología, Campus San Pablo, Barrio Zaragocilla, Cartagena de Indias, Colombia. E-mail: gnavass@unicartagena.edu.co
\end{abstract}

\section{Zoobank: urn:lsid:zoobank.org:pub:CB8DB4E9-BF83-46BD-8B54-EC57BF455488}

KEY WORDS: Woodlice, Oniscidea, New species, Colombian Caribbean, Neotropical.

КЛЮЧЕВЫЕ СЛОВА: мокрицы, Oniscidea, новые виды, карибский регион Колумбии, Неотропика.

ABSTRACT. To date, 17 species of terrestrial isopods are recorded from the Colombian Caribbean. During recent surveys in the Botanical Garden of Cartagena "Guillermo Piñeres", Turbaco, Bolívar, Colombia, six species were recognized, belonging to the families Philosciidae, Scleropactidae, Platyarthridae and Armadillidae, of which three are new to the science, and described here: Colomboniscus carpioi sp.n. (Scleropactidae), Ctenorillo dazai sp.n. (Armadillidae), and Trichorhina bermudezae sp.n. (Platyarthridae). This represents the first record of Ctenorillo to Colombia and of Trichorhina and Colomboniscus to the Colombian Caribbean region. Finally, Venezillo gigas is redescribed.

How to cite this article: Carpio-Díaz Y.M., LópezOrozco C.M., Campos-Filho I.S., Navas-S. G.R. 2018. Terrestrial isopods (Isopoda: Oniscidea) of the Botanical Garden of Cartagena "Guillermo Piñeres", Colombia, with the description of three new species // Arthropoda Selecta. Vol.27. No.4. P.301-318. doi: 10.15298/arthsel. 27.4.05

РЕЗЮМЕ. К настоящему времени с карибского побережья Колумбии известно 17 видов наземных изопод. В результате исследования территории ботанического сада Картахены «Гильермо Пиньерес» (муниципалитет Турбако, департамент Боливар, Колумбия) выявлено 6 видов наземных изопод из семейств Philosciidae, Scleropactidae, Platyarthridae и Armadillidae, три из которых описаны как новые для науки: Colomboniscus carpioi sp.n. (Scleropactidae), Ctenorillo dazai sp.n. (Armadillidae), и Trichorhina bermudezae sp.n. (Platyarthridae). Род Ctenorillo впервые отмечен в фауне Колумбии, а роды Trichorhina и Colomboniscus - в фауне карибского региона Колумбии. Дано переописание Venezillo gigas.

\section{Introduction}

Terrestrial isopods (Oniscidea) constitute one of the most diverse groups within Isopod crustaceans (ca. 3,700 species), and have adapted to various terrestrial environments [Schmalfuss, 2003; Sfenthourakis, Taiti, 2015].

To date, 39 species belonging to 23 genera and 12 families are known from Colombia, occurring from the supralittoral zone to the tropical and mountain forest areas [Richardson, 1912; Pearse, 1915; Vandel, 1972; Taiti et al., 1995; Leistikow, 2001a, b; Schmalfuss, 2003; Schmidt, 2007; Preciado, Martínez, 2014; López-Orozco et al., 2014, 2016, 2017; Carpio-Díaz et al., 2016]. Among them, 17 species are known to the Caribbean region of Colombia, i.e. Ligia baudiniana Milne-Edwards, 1840, L. simoni (Dollfus, 1893) (Ligiidae), Tylos niveus Budde-Lund, 1885 (Tylidae), Androdeloscia colombiana López-Orozco, Carpio-Díaz et Campos-Filho, 2016, Ischioscia curvaculeus Leis- 
tikow, 2001, Pulmoniscus turbanaensis López-Orozco, Carpio-Díaz et Campos-Filho, 2017 (Philosciidae), Colomboscia bituberculata Taiti, Allspach et Ferrara, 1995, C. gaigei (Pearse, 1915), Scleropactes colombiensis (Pearse, 1915) (Scleropactidae), Littorophilosia culebrae (Moore, 1901) (Halophilosciidae), Synarmadillo ruthveni (Pearse, 1915), Venezillo brevispinis (Pearse, 1915), V. gigas (Miers, 1877), V. grenadensis (Budde-Lund, 1893), V. vincentis (Budde-Lund, 1904) (Armadillidae), Agabiformius lentus (Budde-Lund, 1885), and Porcellionides pruinosus (Brandt, 1833) (Porcellionidae) [Richardson, 1912; Pearse, 1915; Leistikow, 2001b; Schmalfuss, 2003; Schmidt, 2007; López-Orozco et al., 2014, 2016, 2017; Carpio-Díaz et al., 2016].

The seasonally dry tropical forest areas (SDTF) have disjunct distribution along the Neotropical region [Pennington et al., 2006; Banda-R et al., 2016], comprising distinct ecosystems and harboring high levels of endemic biota [Lamoreux et al., 2006; Olsen et al., 2001; Morrone, 2014]. The Botanical Garden of Cartagena "Guillermo Piñeres" (BGGP), Turbaco, Bolívar, represents a well conserved area of SDTF and, together with other SDTF areas, are considered priority for conservation [Myers et al., 2000; Banda-R et al., 2016].

Recent surveys in the BGGP allowed us to recognize six species of terrestrial isopods, which belong to the families Philosciidae, Scleropactidae, Platyarthridae and Armadillidae. Among them, three species are new to the science, and described here. In addition, Trichorhina heterophthalma Lemos de Castro, 1964 has the first record from Colombia and V. gigas is redescribed.

\section{Material and methods}

Study area. The BGGP is located at $5 \mathrm{~km}$ from the municipality of Turbaco, sector Matute, north of the department of Bolívar. The botanical garden has an area of nine hectares, including a small patch of native forest, collections of living plants (Arboretum, Palmetum, Fruit trees and Ornamentals), and gardens of mosses and ferns. It is located in an altitude of $130 \mathrm{~m}$ a.s.l., with a temperature of $28^{\circ} \mathrm{C}$, annual precipitation from 900 to $1200 \mathrm{~mm}$, and has three defined seasons (dry, rainy and transition) with annual relative air humidity of approximately 70\% [Alcaldía de Turbaco-Bolívar, 2012].

Sampling, preservation and identification. Direct Intuitive Searches [Taiti, Wynne, 2015] were assumed as hand-collect method. The surveys consisted in searches in moss or fern gardens, earth, fallen leaves, fallen trunks, under rocks, roots and bark of living trees. The estimated time of the searches was about 20 minutes per observer (two observers). The specimens were preserved in $75 \%$ ethanol. The methodology of Vandel [1962] was used to obtain the coordinates of the noduli laterales. The previous records provided here include only the works mentioning Colombia. The images were obtained using an Axio Lab A1 microscope and a ste- reomicroscope SteREO Discovery.V12 ZEISS with an adapted camera Axiocam ERc 5s. The final illustrations were made by using the GIMP Software v2.8.14 (GNU Program for Image Manipulation available at https://www.gimp.org/downloads/) following the methodology of Coleman [2006] and Montesanto [2015, 2016].

The material examined was deposited in the Collection of the Universidad de Cartagena, Cartagena, Colombia (CUDC-CRU) and in the Collection of the Instituto de Ciencias Naturales, Universidad Nacional de Colombia, Bogotá, Colombia (ICN- CI).

\section{Taxonomic part}

Order Isopoda Latreille, 1817

Suborder Oniscidea Latreille, 1802

Family Philosciidae Kinahan, 1857

Genus Androdeloscia Leistikow, 1999

TYPE SPECIES. Chaetophiloscia hamigera Vandel, 1952 [= Androdeloscia hamigera (Vandel, 1952)], by original designation.

DIAGNOSIS. After Leistikow [1999] and Schmidt \& Leistikow [2005]: animals with reduced size, up to $6 \mathrm{~mm}$; cephalon with lateral lobes and frontal line reduced, suprantennal line present; eyes composed of 6-15 ommatidia; noduli laterales very long; antennula with distal article bearing one subapical tuft of aesthetascs plus apical pair; antenna with flagellum of three articles, apical organ long; mandibles with molar pecinil dichotomized; maxillula outer endite of 4 simple teeth on outer set plus 4-6 teeth on inner set, most of them cleft at apex; maxilliped endite with small penicil knob-like; pereopods slender, pereopod 1 carpus with transverse antennal grooming brush; dactylus of two claws, inner claw not surpassing outer claw; uropod protopod and exopod grooved on outer margin bearing glandular pores, endopod inserted proximally; pleopod 1-5 exopods without repiratory structures; male pleopod 1 endopod stout, sometimes bearing complex distal apparatus and/or outer medial lobe; male pleopod 2 endopod very long, male pleopod 5 exopod with medial groove to accommodate endopod 2 , often with medial portion elongated (see also Grangeiro \& Christoferssen, 2010; López-Orozco et al., 2016).

\section{Androdeloscia colombiana López-Orozco, Carpio-} Díaz et Campos-Filho, 2016

Fig. 1.

MATERIAL EXAMINED. $27 \bigcirc^{7} \sigma^{7}, 63$ ㅇ (CUDC-CRU 68), Colombia, Bolívar, Turbaco: Botanical Garden Guillermo Piñeres, $10^{\circ} 20^{\prime} 51.59^{\prime \prime} \mathrm{N}, 75^{\circ} 25^{\prime} 30.79^{\prime \prime} \mathrm{W}, 19.09 .2015$, leg. C.M. López-

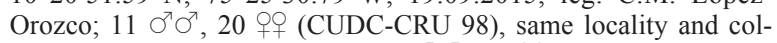
lector as previous, 19.05.2017; $10 \mathrm{O}^{\top} \mathrm{O}^{\top}, 20$ 우 (ICN-CI-92), same data as previous.

DISTRIBUTION. This species is recorded from El Chorro, north of Bolívar, Soplaviento, and in the Botanical Garden "Guillermo Piñeres", Turbaco [López-Orozco et al., 2016].

Family Scleropactidae Verhoeff, 1938 Genus Colomboniscus Vandel, 1972

TYPE SPECIES. Colomboniscus regressus Vandel, 1972, by monotypy. 


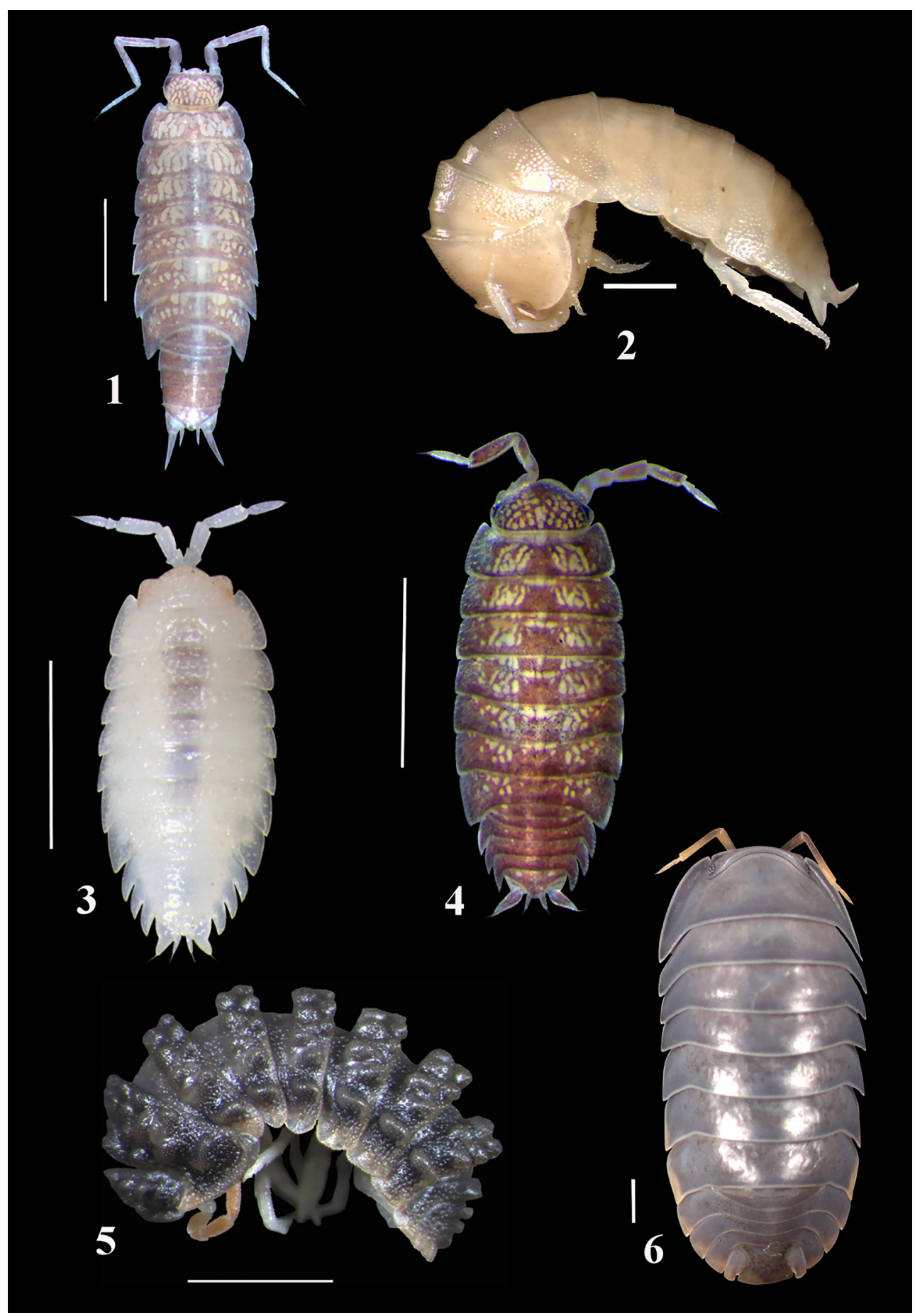

Figs 1-6. Terrestrial isopods from the Botanical Garden "Guillermo Piñeres". Scale bars $1 \mathrm{~mm}$.

1 - Androdeloscia colombiana; 2 - Colomboniscus carpioi sp.n.; 3 - Trichorhina heterophthalma; 4 - Trichorhina bermudezae sp.n.; 5 - Ctenorillo dazai sp.n.; 6 - Venezillo gigas.

Рис. 1-6. Мокрицы ботанического сада “Гильермо Пиньерес”. Масштаб: 1 мм.

DIAGNOSIS. After Schmidt [2007]: animals with maximum size, ca. $4.5 \mathrm{~mm}$; endoantennal conglobation; dorsal surface smooth covered with small and thin triangular scalesetae; cephalon with subtrapezoidal frontal shield, upper margin and corners rounded; frontal shield bent backwards over vertex of cephalon; eyes reduced to pigment spots without lenses, or completely absent; pereopnites 1-7 epi- mera with one line of noduli laterales per side; telson rounded; antennula of three articles, distal article with subapical row of aesthetascs plus apical pair; antenna with flagellum of three articles, apical organ long; mandibles with molar penicil dichotomized; maxillula outer endite with 4 simple teeth on outer set (sometimes with accessory tooth), and 4 or 5 teeth on inner set, most of them cleft at apex; pereopod 1 


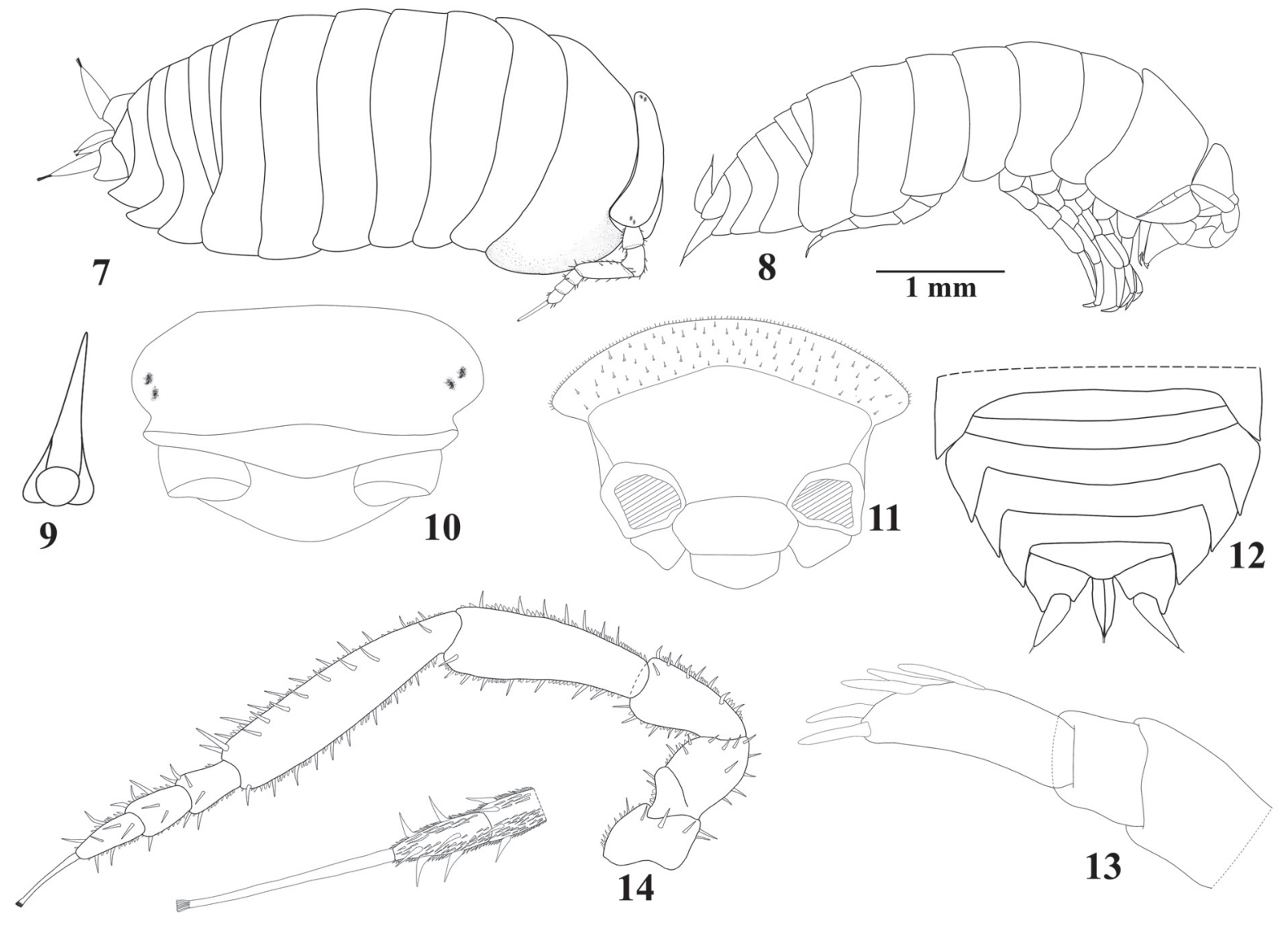

Figs 7-14. Colomboniscus carpioi sp.n., female paratype: 7 - adult specimen, dorsal habitus; 8 - adult specimen, lateral view; 9 dorsal scale-seta; 10 - cephalon, dorsal view; 11 - cephalon, frontal view; 12 - pleonites 3-5, telson and uropods; 13 - antennula; 14 antenna.

Рис. 7-14. Colomboniscus carpioi sp.n., паратип самка: 7 - взрослая особь, дорсально; 8 - взрослая особь, вид сбоку; 9 дорсальные сеты; 10 - голова, дорсально 11 — голова, вид спереди; 12 - плеониты 3-5, тельсон и уроподы; 13 - антеннула; 14 антенна.

carpus 1 with short antennal grooming brush; dactylus of two claws, inner claw not surpassing outer claw; uropod protopod flattened, endopod inserted proximally; pleopod $1-5$ exopods without respiratory structures.

\section{Colomboniscus carpioi Carpio-Díaz, López-Orozco et Campos-Filho, sp.n. \\ Figs 2, 7-28.}

Zoobank: urn:1sid:zoobank.org:act:55DE4EA0-0D42-44C98C8C-17642B938EA5

TYPE MATERIAL. Holotype $\sigma^{7}$ (CUDC-CRU 122), Colombia, Bolívar, Turbaco: Botanical Garden Guillermo Piñeres, $10^{\circ} 20^{\prime}$ $51.59^{\prime \prime} \mathrm{N}, 75^{\circ} 25^{\prime} 30.79^{\prime \prime} \mathrm{W}, 19.09 .2015$, leg. Y. Carpio-Díaz. Paratypes: $1 \sigma^{7}$ (CUDC-CRU 123), same data as holotype; $1+$ (CUDCCRU 124), same data as holotype; $2 O^{7} O^{7}, 6$ ㅇ (ICN-CI-90), same data as holotype; $6 \mathrm{O}^{7} \mathrm{O}^{7}, 4$ O+ (CUDC-CRU 103), same locality and collector as holotype, 19.05.2017; $24 \mathrm{O}^{7} \sigma^{7}, 18$ 우 (CUDCCRU 61), same data as holotype.

DESCRIPTION. Maximum body length: $\sigma^{7} 4.1 \mathrm{~mm}$, + $4.3 \mathrm{~mm}$. Color pale yellowish (Fig. 2). Body convex (Figs 2, 7,8 ). Dorsum covered with tiny triangular scale-setae (Fig. 9). Pereonites 1-7 epimera with one line of noduli laterales per side, near posterior margins and almost at same distance of lateral margins. Cephalon (Figs 10,11) with frontal shield obtuse on medial upper margin and straight lateral margins, bent downwards above vertex; eyes with one pale lent or entirely absent, with small brown ocular spots on usual ommatidia position (Fig. 10). Pereonite 1 without schisma or ventral lobe; pereonites 1-7 gradually more arched; pleonites 3-5 epimera with outline continuous with that of pereonite 7, apex acute and directed backwards (Figs 7, 8, 12). Telson (Fig. 12) with lateral sides almost straight and distal margin rounded. Antennula (Fig. 13) with distal article as long as first and second articles together, bearing three subapical and two apical aesthetascs. Antenna (Fig. 14) with fifth article of peduncle slender; flagellum with articles subequal in length; apical organ longer than distal article of flagellum. Mandibles with molar penicil of many branches; left mandible (Fig. 15) with $2+1$ free penicils, right mandible (Fig. 16) with 1+1 penicils. Maxillula (Fig. 17) inner endite with two long penicils covered with thin setae, distal margin rounded with small outer tip; outer endite of $4+4$ teeth, inner set cleft. Maxilla (Fig. 18) inner lobe rounded and covered with thick setae; outer lobe about twice as wide as inner lobe, covered with thin setae. Maxilliped (Fig. 19) basis rectangular bearing sparse scale-setae; palp with two setae on proximal article, medial and distal articles with two 


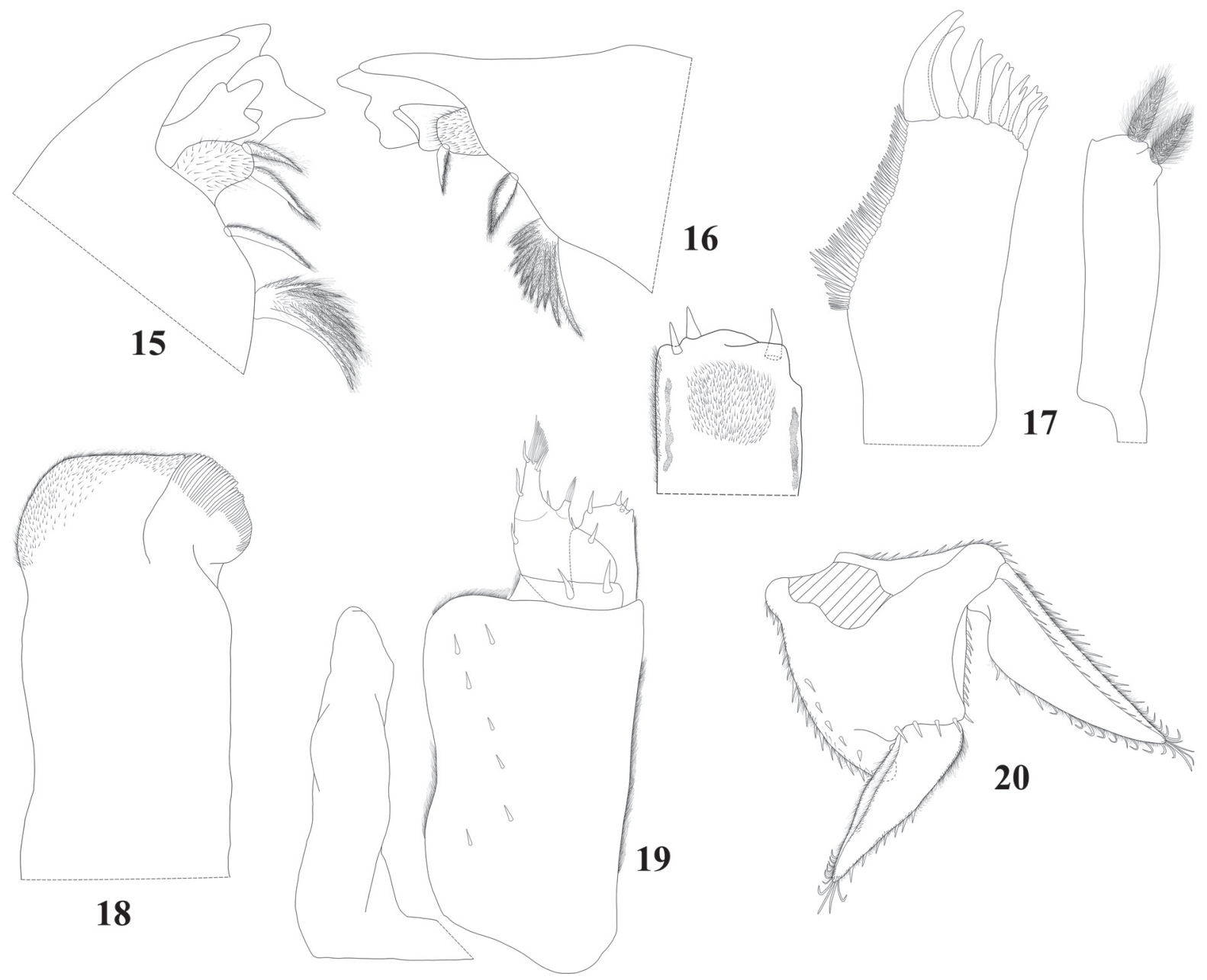

Figs 15-20. Colomboniscus carpioi sp.n., female paratype: 15 - left mandible; 16 - right mandible; 17 - maxillula; 18 - maxilla; 19 - maxilliped; 20 - uropod.

Рис. 15-20. Colomboniscus carpioi sp.n., паратип самка: 15 - левая мандибула; 16 - правая мандибула; 17 — максиллула; 18 максилла; 19 - максиллипед; 20 - уропод.

tufts of setae; endite with medial seta inserted near of distal margin, distal margin irregular bearing two strong setae, ventral portion densely covered with thin setae medially. Uropod (Fig. 20) protopod subquadrangular and bearing many setae on inner and outer margins; endopod longer than exopod and inserted proximally. Pereopods 1-7 merus and carpus with sparse long setae on sternal margin; dactylus with short inner claw, ungual seta and dactylar organ simple and surpassing outer claw.

Male: Pereopod 1 (Fig. 21) merus and carpus bearing fringe of scales on sternal margin; carpus with wide brush of setae. Pereopod 7 (Fig. 22) ischium elongated, sternal margin slightly concave and covered with setae, distal portion with longitudinal depression and bearing transverse row of setae. Genital papilla (Fig. 23) with triangular ventral shield and subapical orifices. Pleopod 1 (Fig. 24) exopod as long as wide, inner and distal margins rounded, outer margin straight, proximal margin concave; endopod about twice as long as exopod, slightly arched bearing small setae along inner margin, distal portion slightly stout with small setae. Pleopod 2 (Fig. 25) exopod triangular, outer margin concave with one seta; endopod stout, longer than exopod.
Pleopod 3 and 4 exopods (Figs 26, 27) rhomboid, outer margin slightly concave with one seta, inner margin sinuous bearing small thin setae. Pleopod 5 exopod (Fig. 28) triangular, outer margin almost straight with two setae, inner margin covered with small setae.

ETYMOLOGY. The new species is named in honor to Mr. Estanislao Carpio for all his assistance during the surveys and stimulus to the graduation for Yesenia Margarita Capio-Díaz as biologist.

REMARKS. To date, Colomboniscus includes two species, i.e., Colomboniscus regressus Vandel, 1972 from the Andean region of Colombia, between 2600-2700 m, Colomboniscus tristani (Arcangeli, 1930) from San José, Costa Rica, and Caripe, Venezuela, and an unnamed species from Tibabitá, Colombia (see Schmidt, 2007). The genus is mainly characterized by endoantennal conglobation ability, eyes reduced, represented by a spot of pigment without lens, or entirely absent, antennal flagellum three-jointed, dorsal surface with short tinny scale-setae, and frontal shield with medial margin rounded (see Schmidt, 2007).

Colomboniscus carpioi sp.n. differs from its congeners in having the frontal shield with lateral margins straight (vs. 


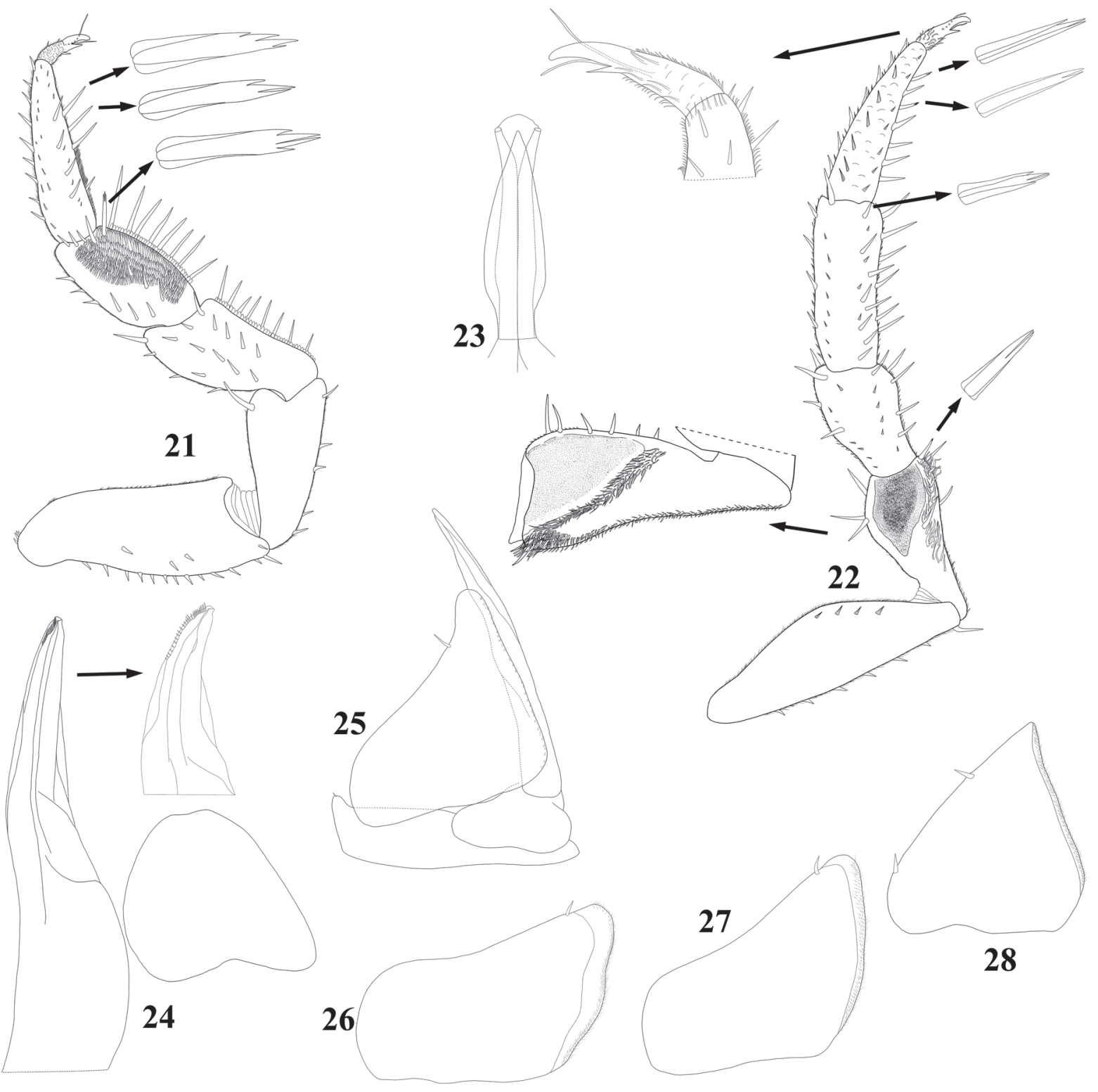

Figs 21-28. Colomboniscus carpioi sp.n., male paratype: 21 - pereopod 1;22 - pereopod 7 (arrow showing the ischium in rostral view); 23 - genital papilla; 24 - pleopod $1 ; 25$ - pleopod $2 ; 26$ - pleopod 3 exopod; 27 - pleopod 4 exopod; 28 - pleopod 5 exopod.

Pис. 21-28. Colomboniscus carpioi sp.n., паратип самец: 21 - переопод 1; 22 - переопод 7 (стрелкой указан исхиум рострально); 23 - генитальная папилла; 24 - плеопод $1 ; 25$ - плеопод 2; 26 - экзопод плеопода $3 ; 27$ - экзопод плеопода 4; 28 экзопод плеопода 5.

rounded in all species), antenna with the fifth article of the peduncle slender and apical organ as long as distal article of flagellum (vs. stout and apical organ longer in all species), male pereopod 7 ischium with longitudinal depression bordered by a row of transverse setae (vs. absent in all species), and male pleopod 1 exopod subtriangular shaped (vs. subrectangular in C. regressus and C. tristani).

Family Platyarthridae Verhoeff, 1949

Genus Trichorhina Budde-Lund, 1908

TYPE SPECIES. Bathytropa thermophila Dollfus, 1896 [= Trichorhina tomentosa (Budde-Lund, 1893)], by original designation.
DIAGNOSIS. After Schmidt [2003] and Souza et al. [2011]: animals of reduced size, up to $6 \mathrm{~mm}$; dorsal pigment varying from absent to brown color; cephalon with lateral lobes well developed, frontal line absent in most species, suprantennal line present; eyes composed of 1-15 ommatidia, or absent in endogean species; dorsal surface smooth, densely covered with fan-shaped scale setae; pereonites 1-7 with one line per side of short noduli laterales, sometimes with two noduli on pereonite 7; telson triangular, sometimes trapezoidal; antennula of three articles; antenna with flagellum of two articles, distal article much longer than proximal one; mandibles with molar penicil simple or dichotomized; maxillula outer endite with outer set composed of 3-5 simple teeth, inner set of 3 or 4 teeth, simple and/or cleft at 


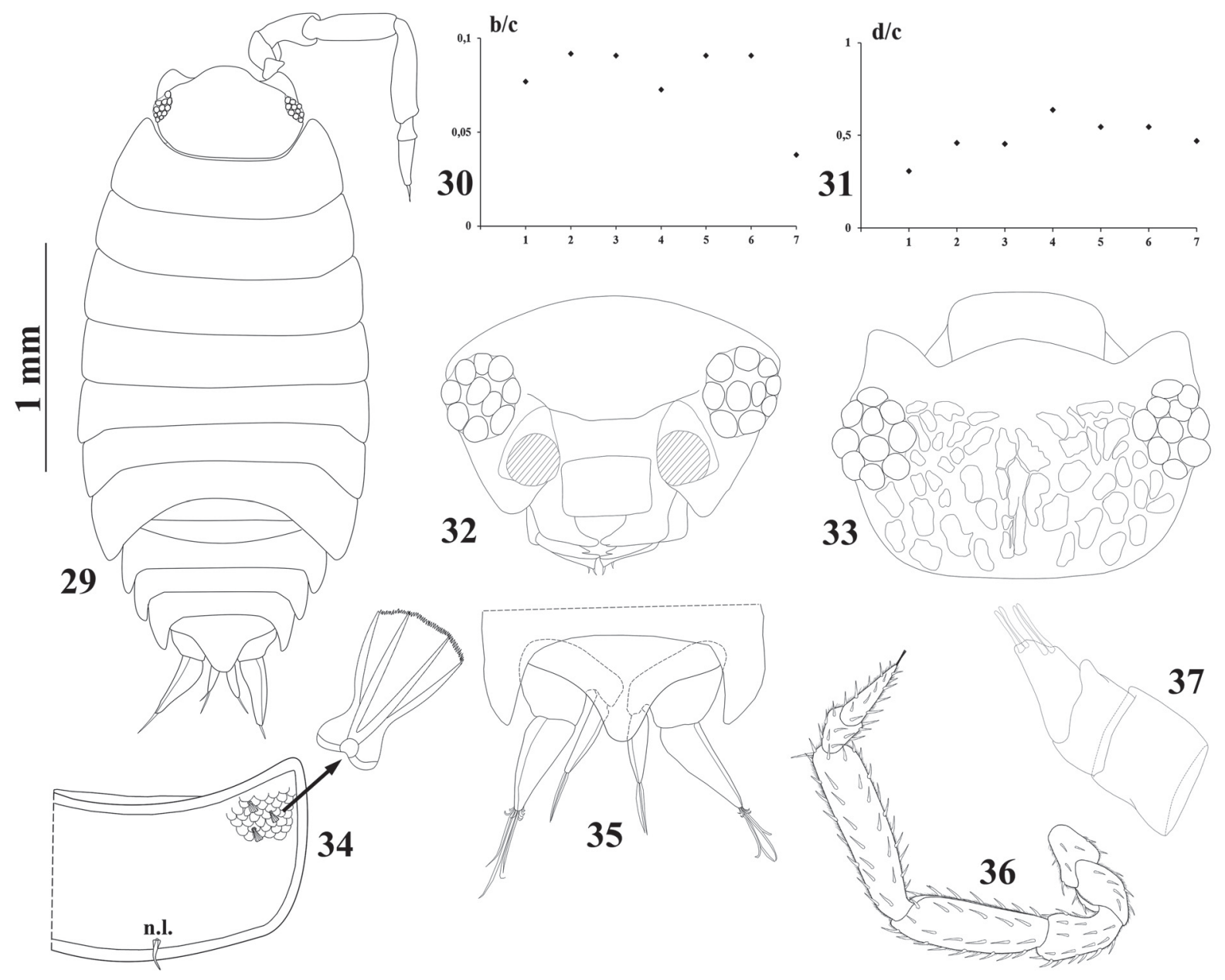

Figs 29-37. Trichorhina bermudezae sp.n., female paratype: 29 - adult specimen, dorsal habitus; 30 - b/c noduli laterales coordinates; $31-\mathrm{d} / \mathrm{c}$ noduli laterales coordinates 32 - cephalon, dorsal view; 33 - cephalon, frontal view; 34 - dorsal scale-seta and nodulus lateralis (n.1.); 35 - telson and uropods; 36 - antennula; 37 - antenna.

Рис. 29-37. Trichorhina bermudezae sp.n., паратип самка: 29 - взрослая особь, дорсально; $30-$ b/c координаты noduli laterales; 31 - d/c координаты noduli laterales; 32 - голова, дорсально; 33 — голова, фронтально; 34 - дорсальные сеты и nodulus lateralis (n.1.); 35 - тельсон и уроподы; 36 - антеннула; 37 - антенна.

apex; pereopod 1 carpus with transverse or longitudinal antennal grooming brush; dactylus of two claws, inner claw not surpassing outer claw; uropod protopod and exopod grooved on outer margin, endopod inserted proximally; male pereopods $1-4$, sometimes 5 , with brush of setae on sternal margin of merus and carpus, sometimes without modifications on both sexes; pleopod 1-5 exopods without respiratory structures.

Trichorhina heterophthalma Lemos de Castro, 1964 Fig. 3.

DIAGNOSIS. Sensu Souza-Kury [1993] and Souza et al. [2011]: cephalon with lateral lobes well developed; eyes composed of two unequally sized ommatidia; pereonite 7 with two noduli laterales per side; antennula with eight distal aesthetascs; antenna with distal article of flagellum twice as long as proximal one; male pereopod 7 ischium slightly concave on sternal margin; male pleopod 1 exopod subcircular; male pleopod 1 endopod more than two times as long as exopod (see also Lemos de Castro, 1964).

MATERIAL EXAMINED. $11 \sigma^{7} \sigma^{7}, 14$ O+ (CUDC-CRU 62), Colombia, Bolívar, Turbaco: Botanical Garden Guillermo Piñeres, $10^{\circ} 20^{\prime} 51.59^{\prime \prime} \mathrm{N}, 75^{\circ} 25^{\prime} 30.79^{\prime \prime} \mathrm{W}, 19.09 .2015$, leg. Y. Carpio-Díaz; $5 \mathrm{O}^{7} \mathrm{O}^{7}, 12$ 우 (CUDC-CRU 99), same locality as previous, 19.05. 2017, leg. C.M. López-Orozco; $50^{7} \sigma^{7}, 8$ 우 (ICN-CI 88), same data as previous.

DISTRIBUTION. Pantropical species [Schmalfuss, 2003]. To date, this species is not recorded from Colombia and, therefore, this work constitutes the first record of the species in this country.

\section{Trichorhina bermudezae Carpio-Díaz, López-Orozco et Campos-Filho, sp.n.}

Figs 4, 29-50.

Zoobank: urn:1sid:zoobank.org:act:048A6F0B-3807-4E29A3CF-BD98FD56954D

TYPE MATERIAL. Holotype $O^{7}$ (CUDC-CRU 125), Colombia, Bolívar, Turbaco: Botanical Garden Guillermo Piñeres, $10^{\circ} 20^{\prime}$ 

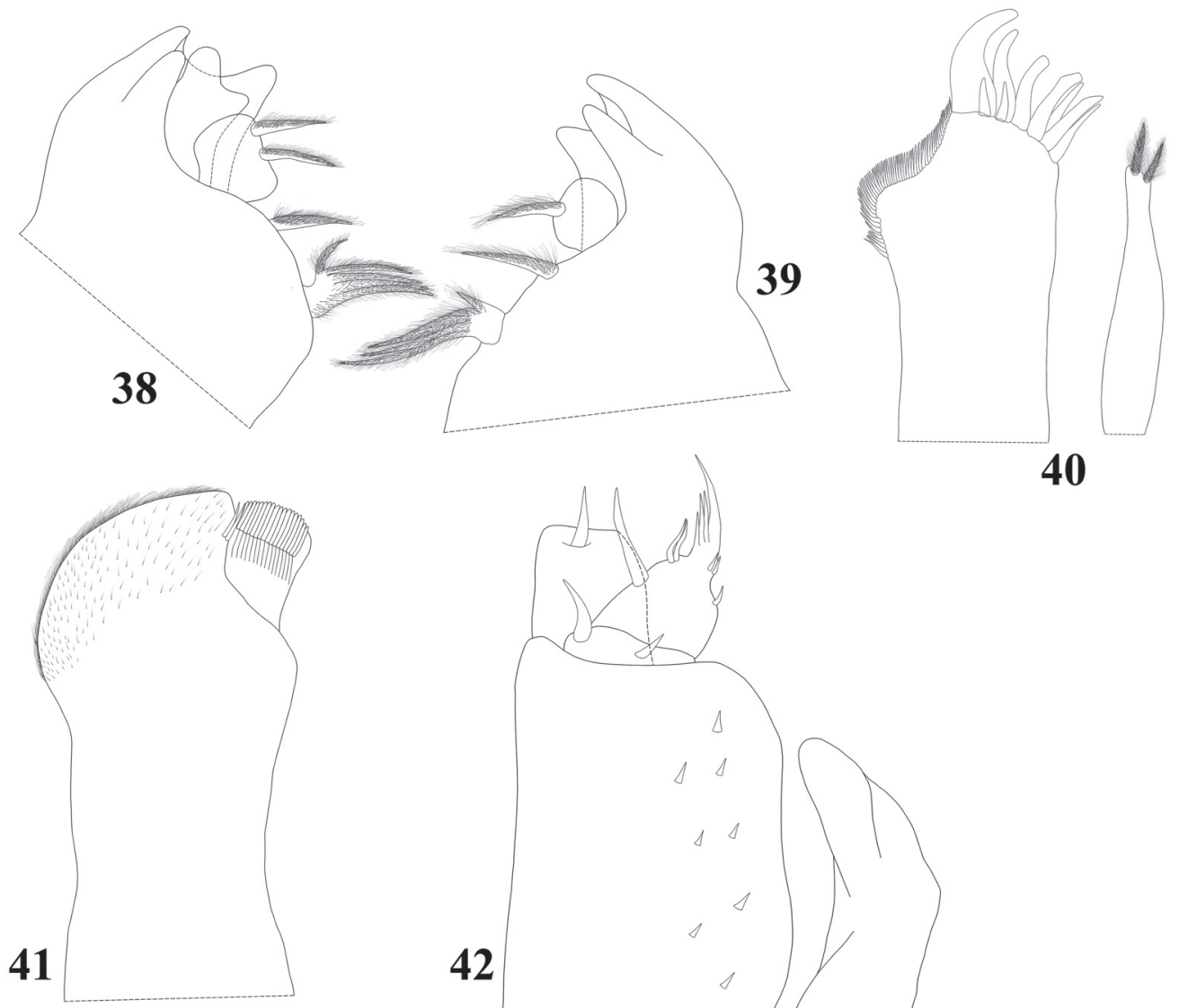

Figs 38-42. Trichorhina bermudezae sp.n., female paratype: 38 - left mandible; 39 - right mandible; 40 - maxillula; 41 maxilla; 42 - maxilliped.

Рис. 38-42. Trichorhina bermudezae sp.n., паратип самка: 38 - левая мандибула; 39 - правая мандибула; 40 - максиллула; 41 — максилла; 42 — максиллипед.

$51.59^{\prime \prime} \mathrm{N}, 75^{\circ} 25^{\prime} 30.79^{\prime \prime} \mathrm{W}, 19.09 .2015$, leg. Y. Carpio-Díaz. Paratypes: 3 +P (CUDC-CRU 126), same data as holotype; $3 \mathrm{O}^{7} \sigma^{7}, 9$ 우 (CUDC-CRU 73), same data as holotype; $10^{7}, 4$ O+ (ICN-CI-92), same data as holotype; 1 + (CUDC-CRU 100), same locality as holotype, 19.05.2017, leg. C.M. López-Orozco.

DESCRIPTION. Maximum body length: $\sigma^{7} 2.9 \mathrm{~mm}$, 우 $3.1 \mathrm{~mm}$. Body convex, outline as in Figs 4, 29. Color brown; antennal peduncle, median portion of pereon, pleon and uropod branches strongly pigmented; cephalon, antenna and uropods with irregular unpigmented spots; pereon with unpigmented areas on paramedian portions; telson with three unpigmented spots (Fig. 4). Dorsal surface scaled, covered with fan-shaped scale-setae (Fig. 34). Pereonites 1-7 epimera with one line of small noduli laterales, inserted close to posterior margins and shifted from lateral margins (Fig. 34); $\mathrm{b} / \mathrm{c}$ and $\mathrm{d} / \mathrm{c}$ coordinates as in Figs 30, 31, respectively. Cephalon (Figs 32, 33) with triangular lateral lobes, slightly directed outwards; suprantennal line slightly bent downwards on middle; eyes composed of ten ommatidia strongly pigmented. Pleon slightly narrower than pereon, epimera 35 well developed and falciform (Figs. 29, 35). Telson (Fig. 35 ) triangular with lateral margins concave, apex narrow with distal margin rounded. Antennula (Fig. 36) with distal article bearing two subapical plus two apical aesthetascs. Antenna (Fig. 37) when extended posteriorly surpassing posterior margin of pereonite 2; distal article of flagellum twice as long as proximal one, with lateral aesthetascs on distal portion; apical organ short. Mandibles with molar penicil consisting of five branches, left mandible (Fig. 38) with $2+1$ penicils, right mandible (Fig. 39) with $1+1$ penicils. Maxillula (Fig. 40) inner endite with two penicils; outer endite with 5+4 simple teeth. Maxilla (Fig. 41) inner lobe subquadrangular, distal margin slightly rounded and covered with thick setae; outer lobe about three times as wide as inner lobe, covered with thin setae. Maxilliped (Fig. 42) basis rectangular bearing sparse scale-setae; palp with two setae distinct in length on proximal article; endite with medial seta surpassing distal margin. Uropod (Fig. 35) protopod subquadrangular; exopod slightly longer than endopod. Pereopod 1 carpus with longitudinal antennal grooming brush and distal setae cleft at apex; dactylus with long inner claw; ungual seta and dactylar organ simple, not surpassing outer claw.

Male: Pereopod 1 (Fig. 43) carpus with brush of setae on sternal margin. Pereopod 7 (Fig. 44) without any particular 


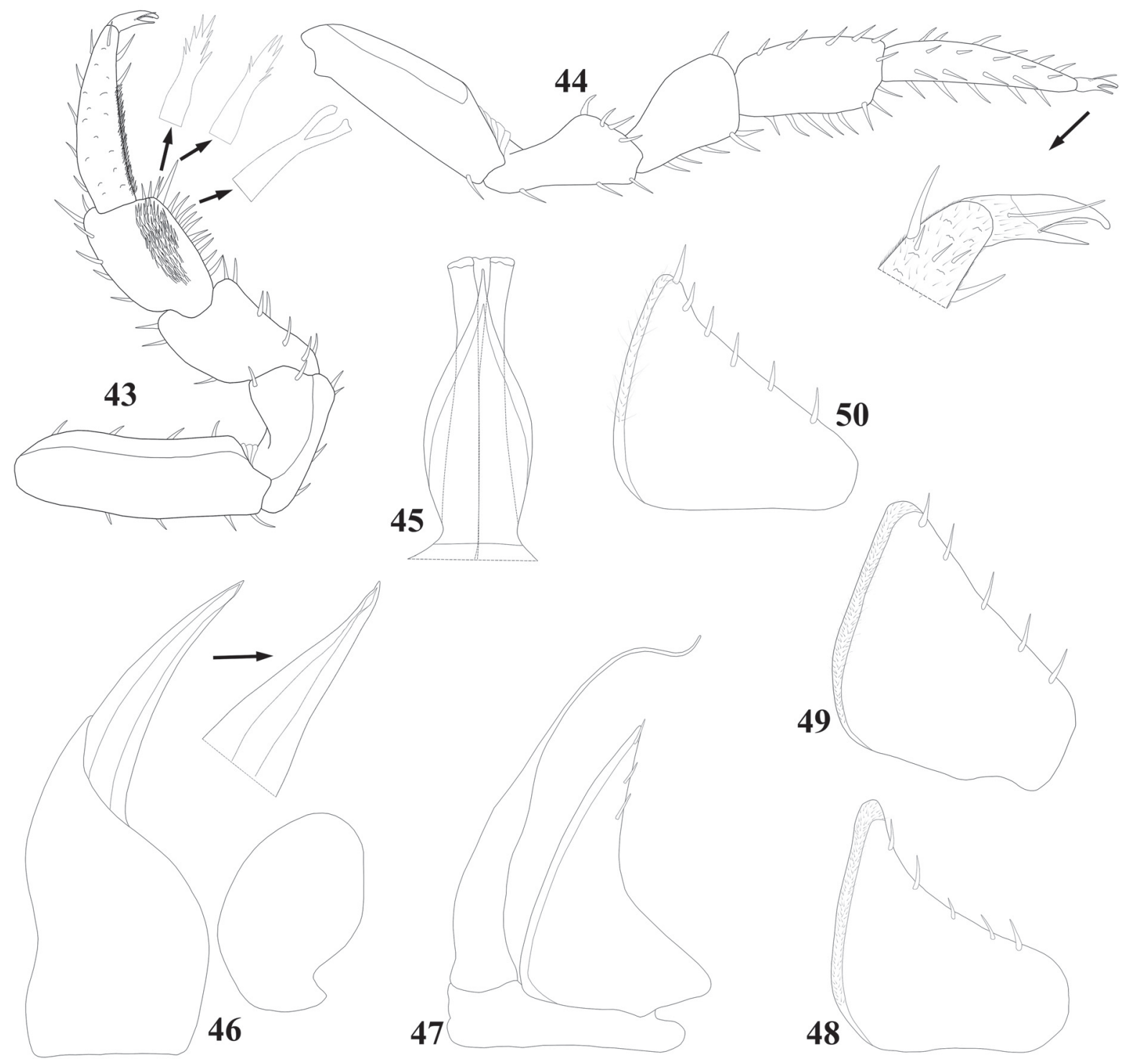

Figs 43-50. Trichorhina bermudezae sp.n., male paratype: 43 — pereopod 1; 44 — pereopod 7; 45 — genital papilla; 46 — pleopod $1 ; 47$ - pleopod 2; 48 - pleopod 3 exopod; 49 - pleopod 4 exopod; 50 - pleopod 5 exopod.

Рис. 43-50. Trichorhina bermudezae sp.n., паратип самец: 43 - переопод 1; 44 - переопод 7; 45 — генитальная папилла; 46 плеопод $1 ; 47$ - плеопод $2 ; 48$ - экзопод плеопода $3 ; 49$ - экзопод плеопода $4 ; 50$ - экзопод плеопода 5.

modification. Genital papilla as in Figure 45. Pleopod 1 (Fig. 46) exopod ovoid; endopod three times as long as exopod, distal portion tapering and directed outwards. Pleopod 2 (Fig. 47) exopod triangular, outer margin concave bearing three setae; endopod flagelliform, longer than exopod, distal portion slender. Pleopod 3 exopod (Fig. 48) triangular, outer margin concave bearing five setae. Pleopod 4 exopod (Fig. 49) triangular, outer margin almost straight bearing five setae. Pleopod 5 exopod (Fig. 50) triangular, outer margin almost straight bearing six setae.

ETYMOLOGY. The new species is named after Dr. Adriana Bermúdez for her contributions to the knowledge of Crustacea from Colombia.

REMARKS. To date, the genus Trichorhina comprises 69 species, of which 44 are recorded from the Neotropical region [Schmalfuss, 2003; Boyko et al., 2008a; Souza et al., 2011; Campos-Filho et al., 2014; Taiti et al., 2018]. In Colombia, only T. papillosa (Budde-Lund, 1893) is recorded from Medellín, department of Antioquia. Trichorhina bermudezae sp.n., together with $T$. heterophthalma, constitute the first records of the genus to the department of Bolívar and Caribbean coast of Colombia.

In having ten ommatidia, T. bermudezae sp.n. is similar to T. amazonica Souza-Kury, 1997, T. mariani Arcangeli, 1930, T. pubescens (Dollfus, 1893) and T. yiara CamposFilho, Araujo et Taiti, 2014; however, it is distinguished by the distal article of antennula with four aesthetascs and shape of male pleopods 1 and 2. 

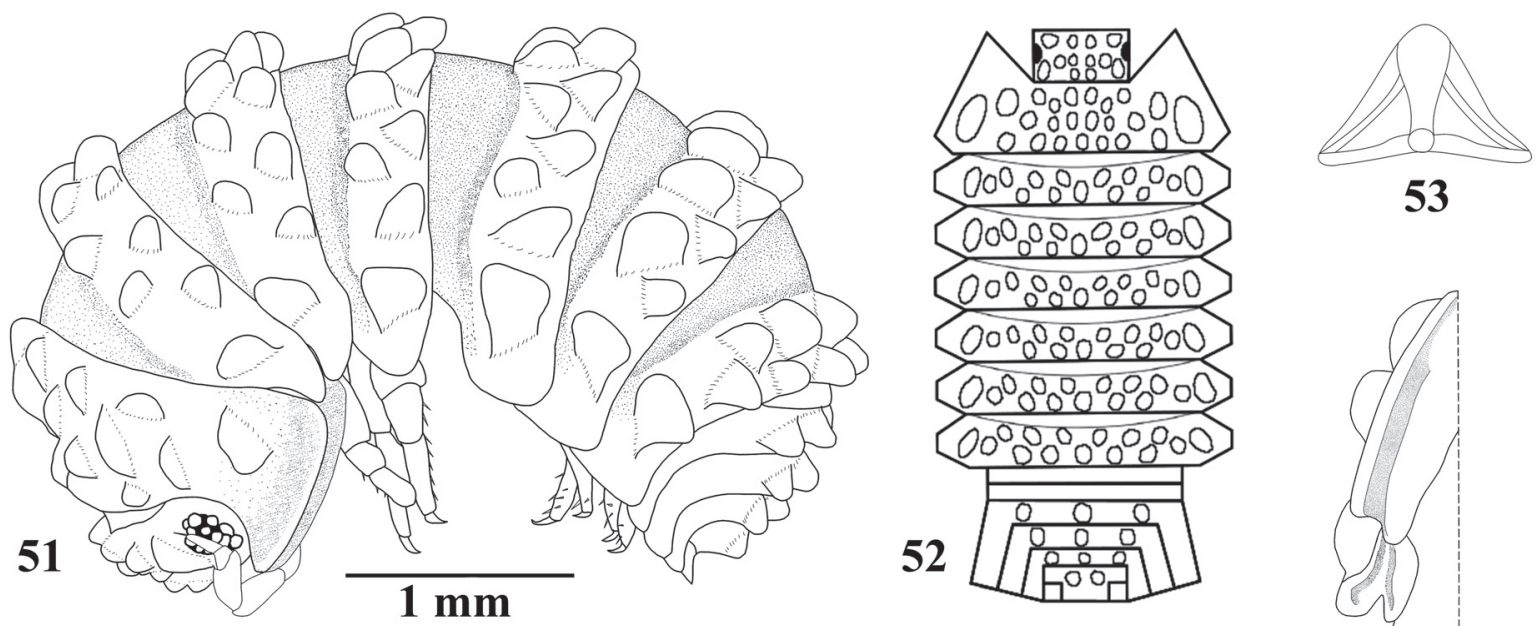

53
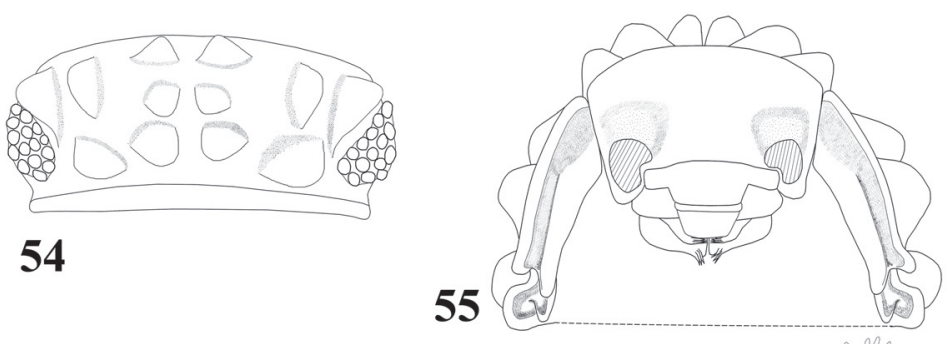

54

55

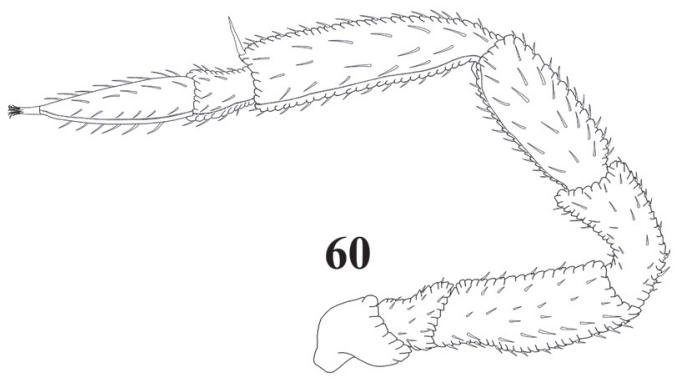

59
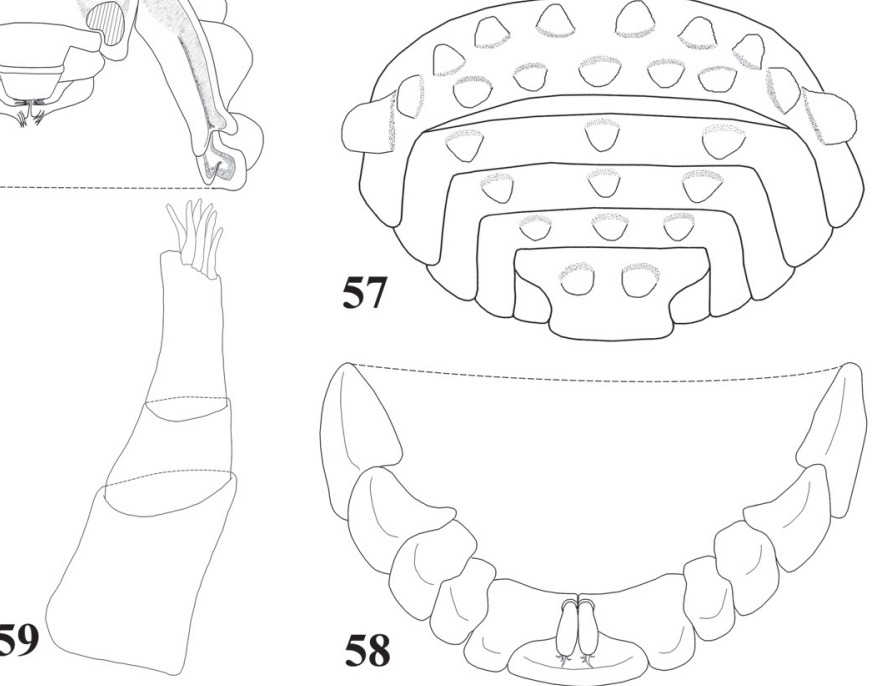

Figs 51-60. Ctenorillo dazai sp.n., female paratype: 51 - adult specimen, lateral view; 52 - disposition of dorsal tubercles; 53 dorsal scale-seta; 54 - cephalon, dorsal view; 55 - cephalon and pereonites 1 and 2, frontal view; 56 - epimera of pereonites 1 and 2 , ventral view; 57 - pleonites $3-5$, telson and uropods, dorsal view; 58 - pleonites $3-5$, telson and uropods, ventral view; 59 - antennula; 60 - antenna.

Рис. 51-60. Ctenorillo dazai sp.n., паратип самка: 51 - взрослая особь, вид сбоку; 52 - расположение досальных бугорков; 53 - дорсальные сеты; 54 - голова, дорсально; 55 - голова и переониты 1 и 2, вид спереди; 56 - эпимеры переонитов 1 и 2 , вентрально; 57 - плеониты 3-5, тельсон и уроподы, дорсально; 58 - плеониты 3-5, тельсон и уроподы, вентрально; 59 антеннула; 60 - антенна.

Family Armadillidae Brandt, 1831

Genus Ctenorillo Verhoeff, 1942

TYPE SPECIES. Ctenorillo buddelundi Verhoeff, 1942 [= Ctenorillo regulus (Van Name, 1920)], by monotypy.

DIAGNOSIS. After Schmalfuss \& Ferrara [1983] and Taiti et al. [1998]: animals with reduced size and strongly convex; endoantennal conglobation; cephalon, pereon and pleon with dorsal surface bearing more or less developed ribs and/or tubercles; cephalon with frontal shield subquadrangular; pereonite 1 epimera with schisma; pereonites 1 and 2 with ventral lobe, pereonite 2 with triangular lobe; pereonites 1-7 with one line of tiny noduli laterales per side; telson hour-glass shaped; antennula of three articles; antenna with flagellum of two articles, distal article longer than proximal one; mandibles with molar penicil dichotomised or semidichotomised; maxillula with simple teeth; pereopod 1 carpus with transverse antennal grooming brush; dactylus of two claws, inner claw not surpassing outer claw; uropod subquadrangular, protopod flattened with concave medial margin, exopod tiny inserted near medial margin; pleopod 1-5 exopods with monospiracular covered lungs (see also Campos-Filho et al., 2014, 2017; Taiti, 2018). 

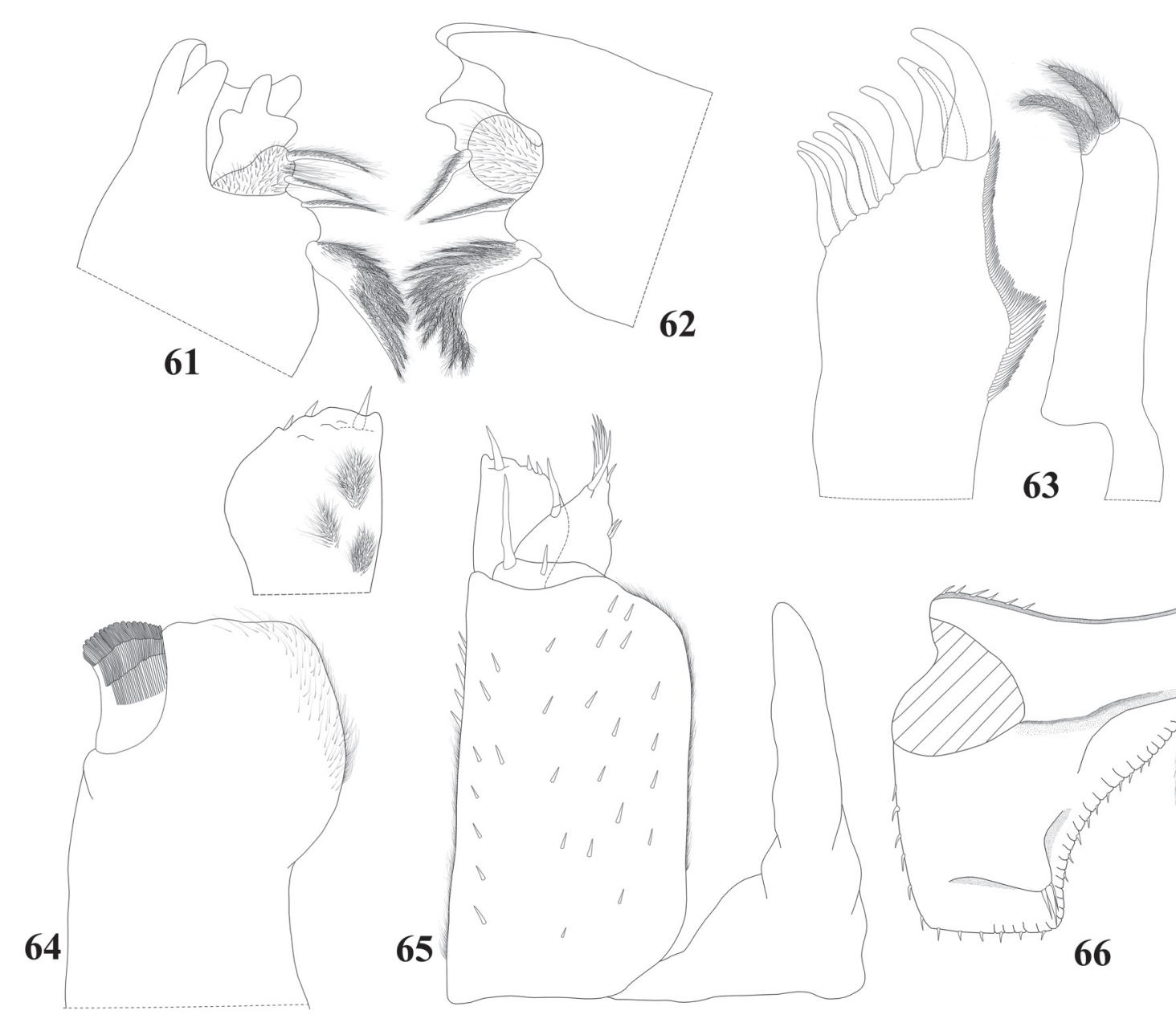

Figs 61-66. Ctenorillo dazai sp.n., female paratype: 61 - left mandible; 62 — right mandible; 63 - maxillula; 64 - maxilla; 65 maxilliped; 66 - uropod.

Рис. 61-66. Ctenorillo dazai sp.n., паратип самка: 61 - левая мандибула; 62 - правая мандибула; 63 - максиллула; 64 максилла; 65 - максиллипед; 66 - уропод.

\section{Ctenorillo dazai Carpio-Díaz, López-Orozco et Campos-Filho, sp.n. Figs 5, 51-74.}

Zoobank: urn:1sid:zoobank.org:act:85D692EE-471F-48FBA6BE-5553EFDB05E3

TYPE MATERIAL. Holotype $\sigma^{7}$ (CUDC-CRU 119), Colombia, Bolívar, Turbaco: Botanical Garden Guillermo Piñeres, $10^{\circ} 20^{\prime}$ $51.59^{\prime \prime} \mathrm{N}, 7^{\circ} 25^{\prime} 30.79^{\prime \prime} \mathrm{W}, 19.09 .2015$, leg. Y. Carpio-Díaz. Paratypes: $1 \mathrm{O}^{7}$ (CUDC-CRU 120), same data as holotype; 1 (CUDCCRU 121), same data as holotype; $10^{7}, 2$ 우 (ICN-CI 89), same data as holotype; 1 + (CUDC-CRU 102), same locality as holotype, 19.05.2017, leg. C.M. López-Orozco; 5 O $^{7} \sigma^{7}, 2$ 우 (CUDC-CRU 51), same data as previous.

DESCRIPTION. Maximum body length: $\sigma^{\top} 3 \mathrm{~mm}, ~ \rightarrow 4.2$ mm. Color dark brown (Fig. 5). Dorsum covered with large ribs and tubercles, arranged as follows (Figs 51, 52, 54, 57): vertex of cephalon with three rows, one anterior row of four tubercles, one middle row of six tubercles and posterior row of two tubercles; pereonite 1 with anterior row of six tubercles, middle row of ten tubercles and posterior row of seven tubercles; pereonites 2-7 with anterior row of ten tubercles and posterior row of five tubercles; pleonites $3-5$ with row of three tubercles each; telson with two tubercles. Dorsal surface with verruca-like prominences and short triangular scale-setae (Fig. 53). Pereonites 1-7 with noduli laterales inserted on lateral surface of second outer tubercle. Cephalon (Figs 54, 55) with frontal shield slightly protruding above vertex; eyes consisting of 17 ommatidia. Pereonite 1 epimera grooved on lateral margins, inner lobe of schisma rounded, extending beyond posterior margin of outer lobe; pereonite 2 with ventral lobe slightly triangular, extending beyond three quarts of its length (Figs 55, 56); epimera of pereonites 2-4 subtriangular, 5-7 subquadrangular (Fig. 51). Telson (Fig. 57, 58) with proximal portion broader than distal portion, distal margin truncated. Antennula (Fig. 59) with distal article bearing six apical aesthetascs. Antenna (Fig. 60) short and stout, surpassing posterior margin of cephalon when extended backwards; flagellum with distal article twice as long as proximal one; apical organ short, about $1 / 3$ as long as distal article of flagellum. Mandibles with molar penicil semidichotomised consisting of several branches, left mandible (Fig. 61) with $2+1$ penicils, right mandible (Fig. 62) with $1+1$ penicils. Maxillula (Fig. 63) inner endite with two long penicils; outer endite of $4+5$ 


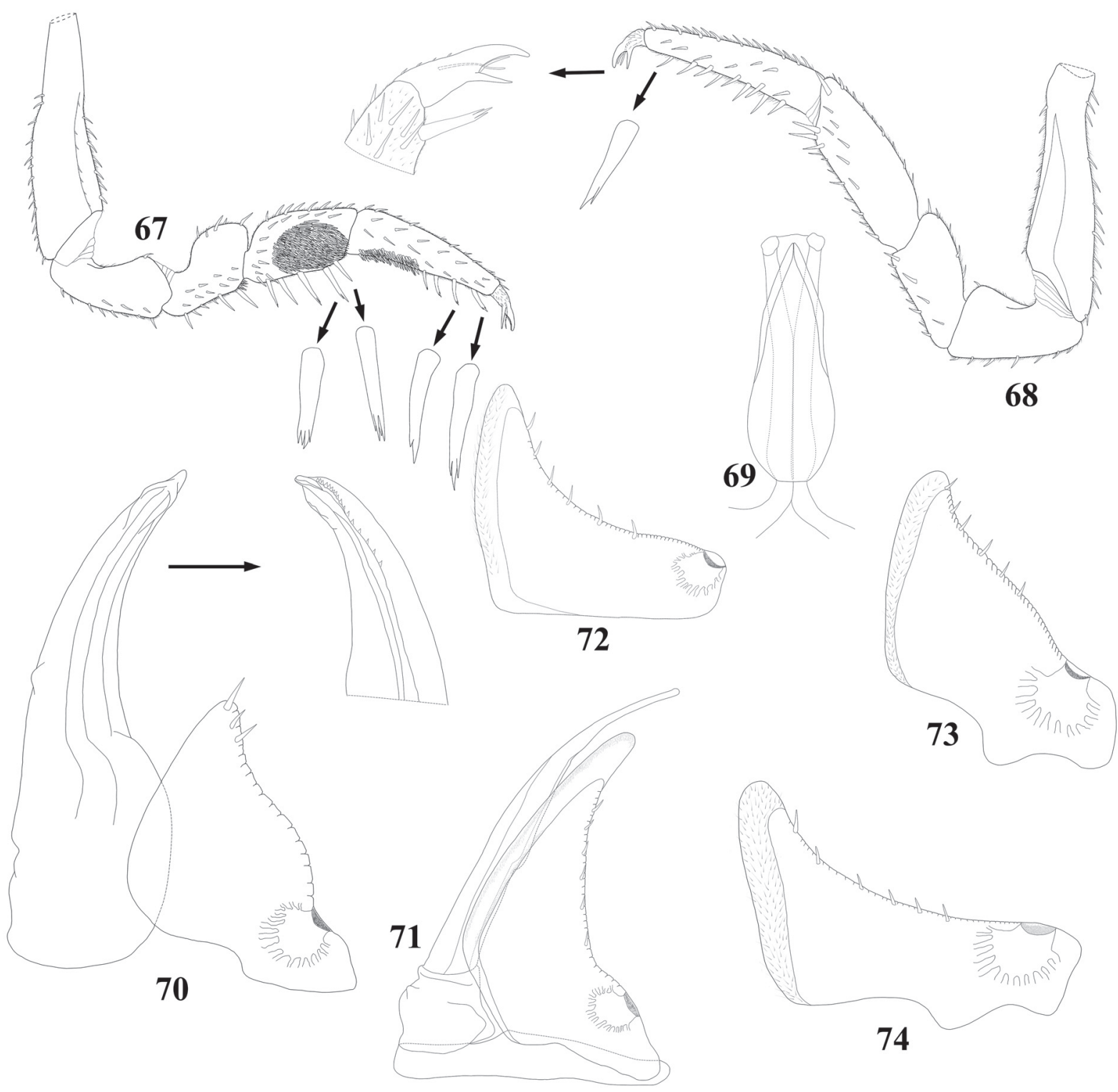

Figs 67-74. Ctenorillo dazai sp.n., male paratype: 67 — pereopod $1 ; 68$ — pereopod 7; 69 — genital papilla; 70 - pleopod 1 (arrow showing the detail in ventral view); 71 - pleopod 2; 72 - pleopod 3 exopod; 73 — pleopod 4 exopod; 74 - pleopod 5 exopod.

Рис. 67-74. Ctenorillo dazai sp.n., паратип самец: 67 - переопод 1; 68 - переопод 7; 69 - генитальная папилла; 70 плеопод 1 (стрелкой показана вентрально часть плеопода); 71 - плеопод 2; 72 — экзопод плеопода $3 ; 73$ - экзопод плеопода 4; 74 - экзопод плеопода 5.

simple teeth. Maxilla (Fig. 64) inner lobe truncated covered with thick setae; outer lobe three times as wide as inner lobe, covered with thin setae. Maxilliped (Fig. 65) basis subrectangular; palp with two setae distinct in length on proximal article; endite with medial seta surpassing distal margin, distal margin with two setae. Uropod (Fig. 66) protopod flattened, enlarged on basal portion, distal portion trapezoidal; exopod very short, inserted dorsally near medial margin of protopod; endopod stout, not surpassing distal margin of protopod. Pereopod 1 carpus with transverse antennal grooming brush; dactylus with long inner claw; ungual seta and dactylar organ simple, not surpassing outer claw.

Male: Pereopods 1 and 7 without particular modifications (Figs 67, 68). Genital papilla (Fig. 69) with triangular ventral shield, papilla slightly surpassing ventral shield with apical orifices. Pleopod 1 (Fig. 70) exopod wider than longer, outer distal margin bearing three setae, outer margin sinuous and inner margin straight; endopod with distal portion triangular, slightly swollen, bent outwards and bearing small setae on the caudal surface near distal margin. Pleopod 2 (Fig. 71) exopod triangular, outer margin concave bearing six setae, inner margin with strong edge, almost straight; endopod longer than exopod. Pleopod 3 exopod (Fig. 72) triangular, outer margin strongly concave bearing six setae. Pleopod 4 exopod (Fig. 73) rhomboid, outer margin slightly sinuous bearing six setae. Pleopod 5 exopod (Fig. 74) rhomboid, outer margin concave bearing six setae, inner margin almost straight. 
ETYMOLOGY. The new species is named after Mr. Mario López Daza, for all his interest in nature and support and encouragement to Carlos Mario López-Orozco as biologist.

REMARKS. To date, the genus Ctenorillo comprises 14 species, of which three are recorded from the Neotropical region [Schmalfuss, 2003; Boyko et al., 2008b; CamposFilho et al., 2014, 2017], i.e., C. mineri (Van Name, 1936) from Brazil, Guyana and Venezuela; C. ferrarai CamposFilho, Araujo et Taiti, 2014 from Brazil; and C. tuberosus (Budde-Lund, 1904) from Brazil, Haiti and Germany (introduced).

Ctenorillo dazai sp.n. is readily distinguished from all the other species of the genus in the number and arrangement of the dorsal tubercles on cephalon, pereon and pleon.

\section{Genus Venezillo Verhoeff, 1928}

TYPE SPECIES. Armadillo clausus Budde-Lund, 1885 [= Venezillo clausus (Budde-Lund, 1885)], by monotypy.

DIAGNOSIS. After Arcangeli [1957] and Schultz [1995]: animals with conglobation ability; body strongly convex; dorsal surface of cephalon, pereon and pleon smooth, sometimes with tubercles and/or bosses; cephalon with subquadrangular frontal shield; pereonite 1 epimera with schisma; pereonites 1 and 2 epimera with ventral lobe; pereonite 2 with ventral lobe elongated, directed backwards; pereonites 1-7 with one line of noduli laterales per side; telson hourglass shaped; antennula of three articles; antenna with flagellum of two articles, distal article longer than proximal one; mandibles with molar penicil dichotomized; maxillula outer endite of simple teeth; uropod protopod flattened with medial margin concave, exopod inserted near medial margin; pleopod 1-5 exopods with monospiracular covered lungs (see also Taiti et al., 1998).

Venezillo gigas (Miers, 1877) Figs 6, 75-97.

Cubaris gigas Miers, 1877: 666, Pl. LXVIII, fig. 1; Richardson, 1901: 572; 1905: 648, fig. 691; Pearse, 1915: 44; Arcangeli, 1930: 2; Van Name, 1936: 363, figs 218 \& 219

Armadillo gigas Budde-Lund, 1879: 7; 1885: 40; 1904: 108

Venezillo (Venezillo) gigas Arcangeli, 1957: 116.

Venezillo gigas Leistikow \& Wägele, 1999: 48; Schmalfuss, 2003: 288

MATERIAL EXAMINED. 9 ○ึ $\sigma^{\top}, 8$ 우 (CUDC-CRU 63), Colombia, Bolívar, Turbaco: Botanical Garden Guillermo Piñeres, $10^{\circ} 20^{\prime} 51.59^{\prime \prime} \mathrm{N}, 75^{\circ} 25^{\prime} 30.79^{\prime \prime} \mathrm{W}, 10.02 .2015$, leg. Y. Carpio-Díaz; $1 \sigma^{7}, 2$, 2 (CUDC-CRU 52), same locality and collector as previous, 19.09.2015; 31 Oొ $^{7}, 74$ o 7 (CUDC-CRU 64), same data as previous; $8 \sigma^{7} \sigma^{7}, 17$ 우 (ICN-CI 91), same data as previous; 27 $\sigma^{7} \sigma^{7}, 50$ 90 (CUDC-CRU 60), same data and locality, leg. C.M. López-Orozco; 1 ( (CUDC-CRU 65), same data as previous; $1 \sigma^{7}$, 11 우 (CUDC-CRU 101), same locality, 19.05.2017, leg. Y. Carpio-Díaz.

PREVIOUS RECORDS. Fundación, department of Magdalena [Pearse, 1915].

RE-DESCRIPTION. Maximum body length: $\sigma^{7} 12 \mathrm{~mm}$, † $14 \mathrm{~mm}$. Color dark gray; pereonites 5-7 and pleonites 3-5 epimera with orange pigmented lateral edges (Fig. 6). Pereonites 1-7 with posterior margin gradually arched, pleonites 3-5 epimera well developed with outline following that of pereonite 7; uropod filling gap between pleonite 5 and telson, conferring a continuous aspect (Figs 75, 76). Endoantennal conglobation. Dorsum smooth, covered with small scale-setae. Cephalon (Fig. 77, 78) with frontal shield protruding above vertex and slightly concave on middle; eyes consisting of 20 ommatidia. Pereonite 1 epimera grooved on lateral margin, about $1 / 3$ as long as epimera; inner lobe of schisma rounded, not extending beyond posterior margin of outer lobe; pereonite 2 with oblique ventral lobe, not extending beyond posterior margin of epimera; pereonite 3 with slightly inner lobe (Figs 78, 79). Pereonites 2-7 epimera subquadrangular, gradually more acute and directed backwards (Fig. 76). Telson hourglass-shaped (Figs 80, 81), proximal portion narrower than distal portion, distal margin slightly rounded. Antennula (Fig. 82) with distal article longest bearing nine subapical aesthetascs. Antenna (Fig. 83) short and slender, not surpassing pereonite 2 when extended backwards; flagellum with distal article twice as long as proximal one; apical organ short, $1 / 3$ as long as distal article of flagellum. Mandibles with molar penicil consisting of several plumose setae, left mandible (Fig. 84) with $2+1$ penicils, right mandible (Fig. 85) with $1+1$ penicils. Maxillula (Fig. 86) inner endite with two long penicils; outer endite bearing of $4+5$ teeth (five of them cleft at apex). Maxilla (Fig. 87) inner lobe rounded covered with thick setae; outer lobe three times as wide as inner lobe and covered with thin setae. Maxilliped (Fig. 88) basis subrectangular, outer margin rounded covered with thin setae; palp with two setae distinct in length on proximal article; endite with medial seta surpassing distal margin, distal margin truncated bearing two strong setae. Uropod (Fig. 89) protopod enlarged on basal portion, distal portion elongated and trapezoidal; exopod short, inserted dorsally near medial margin of protopod; endopod not surpassing distal margin of protopod. Pereopods 1-7 merus and carpus with sparse setae on sternal margin, carpus 1 with longitudinal antennal grooming brush; dactylus with long inner claw, ungual seta and dactylar organ simple, not surpassing outer claw.

Male: Pereopods without particular modifications (Figs 90, 91). Genital papilla (Fig. 92) with triangular ventral shield, papilla slightly surpassing ventral shield with two subapical orifices. Pleopod 1 (Fig. 93) exopod subtriangular, wider than longer, outer margin almost straight, distal margin rounded; endopod three times as long as exopod, distal portion tapering, directed outwards and bearing small setae on median margin. Pleopod 2 (Fig. 94) exopod triangular, outer margin strongly concave, inner margin with strong edge; endopod slightly longer than exopod. Pleopod 3 exopod (Fig. 95) triangular, outer margin concave. Pleopod 4 exopod (Fig. 96) rhomboid, outer margin concave. Pleopod 5 exopod (Fig. 97) rhomboid, outer margin almost straight.

REMARKS. The genus Venezillo comprises 136 species, of which 51 are recorded from the Neotropical region [Schmalfuss, 2003; Boyko et al., 2008c].

Miers [1877] described Cubaris gigas from Nicaragua. Budde-Lund [1885] placed the species into the genus Armadillo Latreille, 1802 without a clear explanation. Arcangeli [1957] based in the work of Vandel [1952] moved this species to the genus Venezillo. Regarding the diagnostic characters of the genus (see Arcangeli, 1957; Schultz, 1995), $V$. gigas is easily recognized by the large size of adult specimens $(>14 \mathrm{~mm})$, shape of the schisma on pereonite 1 epimera, pereonite 2 with ventral lobe oblique, and pereonite 3 with small ventral lobe.

DISTRIBUTION. Nicaragua, San Juan; Costa Rica; Colombia, Magdalena (Fundación) [Miers, 1877; Pearse, 1915; Schmalfuss, 2003]. 


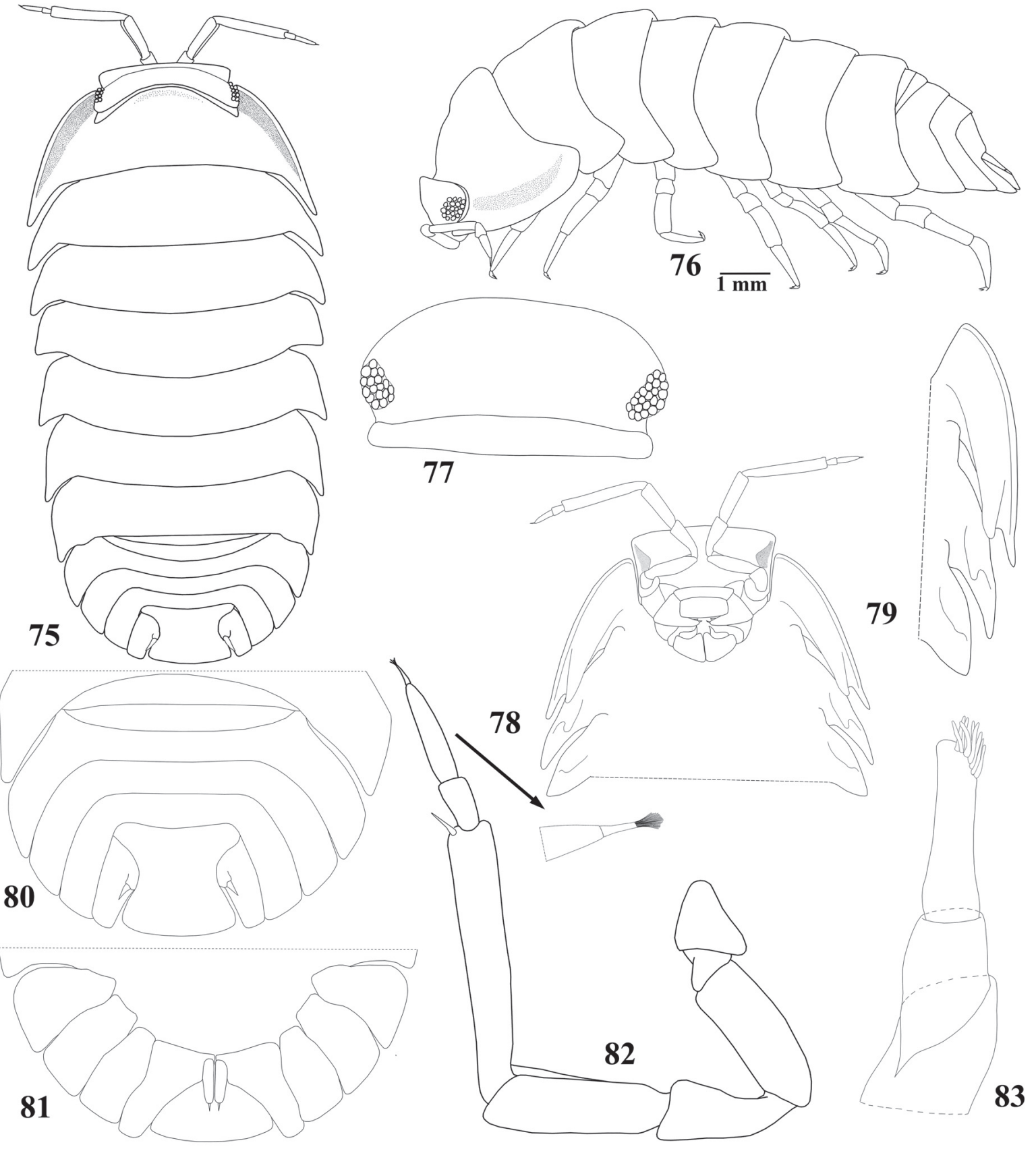

Figs 75-83. Venezillo gigas (Miers, 1877), female: 75 — adult specimen, dorsal habitus; 76 — adult specimen, lateral view; 77 — cephalon, dorsal view; 78 - cephalon and pereonites 1-3, frontal view; 79 - epimera of pereonites 1-3, ventral view; 80 - pleonites 35, telson and uropods, dorsal view; 81 - pleonites 3-5, telson and uropods, ventral view; 82 — antennula; 83 - antenna.

Рис. 75-83. Venezillo gigas (Miers, 1877), самка: 75 - взрослая особь, дорсально; 76 - взрослая особь, вид сбоку; 77 голова, дорсально; 78 - голова и переониты 1-3, вид спереди; 79 - эпимеры переонитов 1-3, вентрально; 80 - плеонтиы 3-5, тельсон и уроподы, дорсально; 81 — плеониты 3-5, тельсон и уроподы, вентрально; 82 — антеннула; 83 - антенна.

\section{Conclusions}

The present study recognized six species of terrestrial isopods from the BGGP (Fig. 1), i.e., Androdeloscia colombiana, Colomboniscus carpioi sp.n., Trichorhina heterophthalma, Trichorhina bermudezae sp.n., Ctenorillo dazai sp.n., and Venezillo gigas. Only
A. colombiana have been recorded from the BGGP [López-Orozco et al., 2016], and $V$. gigas from Fundación [Pearse, 1915], both places at the Caribbean coastal region of Colombia. Trichorhina heterophthal$m a$ is widely distributed in the Neotropical region [Lemos de Castro, 1964; Schmalfuss, 2003]; however, it is first recorded in Colombia in this study. Finally, $V$. 

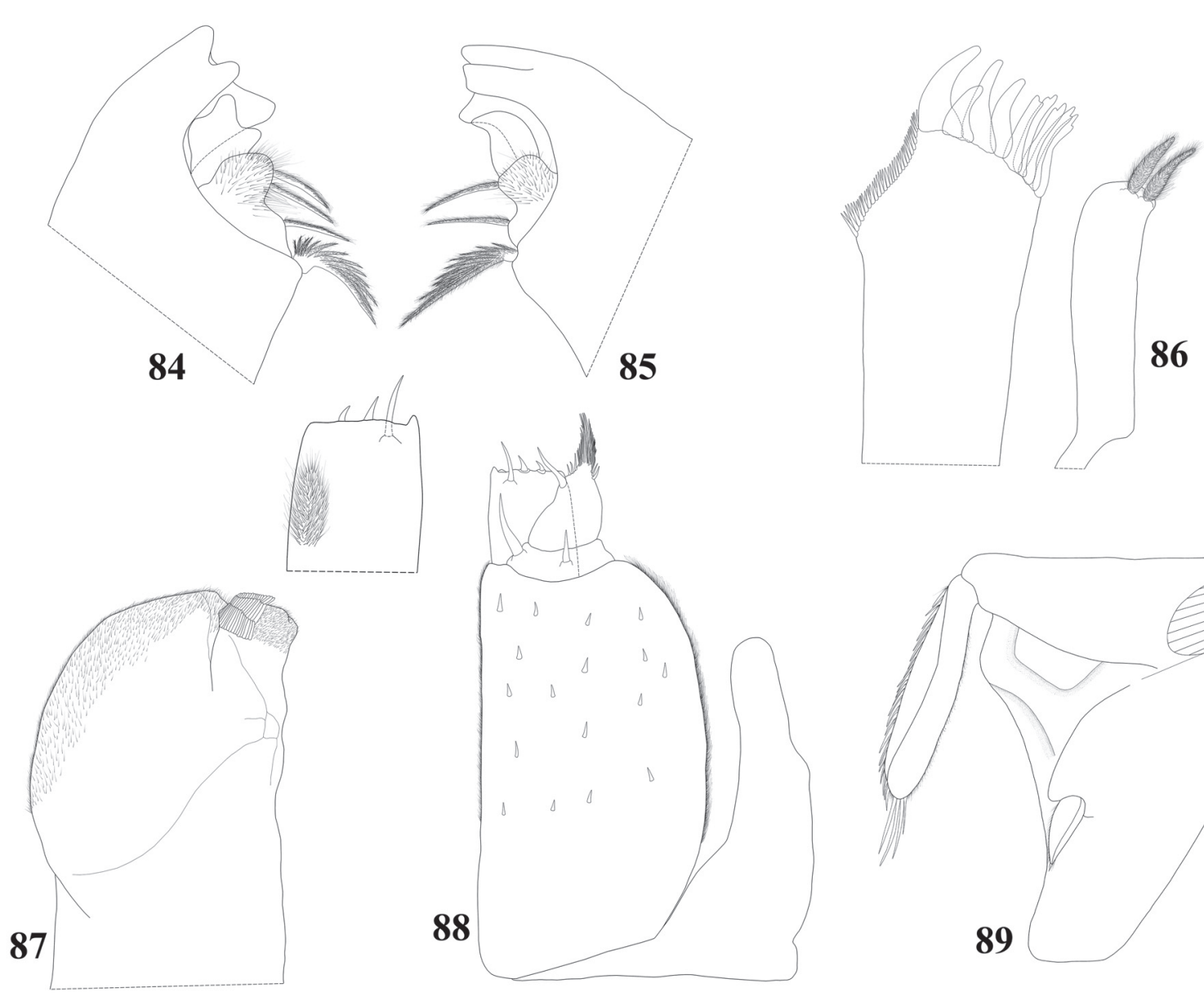

Figs 84-89. Venezillo gigas (Miers, 1877), female: 84 — left mandible; 85 — right mandible; 86 — maxillula; 87 — maxilla; 88 maxilliped; 89 - uropod.

Рис. 84-89. Venezillo gigas (Miers, 1877), самка: 84 - левая мандибула; 85 - правая мандибула; 86 - максиллула; 87 максилла; 88 - максиллипед; 89 - уропод.

gigas originally described from Nicaragua [Miers, 1877], and recorded from Costa Rica and Colombia [Pearse, 1915; Van Name, 1936; Schmalfuss, 2003], is first recorded for the department of Bolívar.

Regarding the 17 species recorded from Caribbean coasts of Colombia, four species have been found in tropical dry forest (TDF) areas: A. colombiana, $P$. turbanaensis, V. gigas and $V$. grenadensis [Richardson, 1912; Pearse, 1915; López-Orozco et al., 2016, 2017]. Our work increases the known diversity of terrestrial isopods from the Caribbean regions of Colombia to 21 species, and 43 species to the country. Considering the current diversity of ecosystems of Colombia [Etter, van Wyngaarden, 2000; Olsen et al., 2001], and the number of known species of Oniscidea, future investigations are necessary to have a better understanding about the diversity and relationships of the group along the Colombian territory.

\section{Acknowledgements}

We are grateful to the management of the Botanical Garden of Cartagena "Guillermo Piñeres" for the permission to conduct this study; to Vicerrectoría de Investigaciones of the University of Cartagena for the financial support to the Grupo de Investigación Hidrobiología (Resolution $N^{\circ} 02482$, 2016); to Alejandro Segovia and Daniela Ahumada for supporting during collections; to Dr. Luis A. Hurtado, from the Texas A\&M University, for his comments; to Dr. Stefano Taiti from the Instituto per lo Studio degli Ecosistemi, Consiglio Nazionale delle Ricerche (Florence, Italy) for his assistance with the generic diagnosis and Latin spelling; to Coordenação de Aperfeiçoamento de Pessoal de Nível Superior for the fellowship granted to Ivanklin Soares Campos-Filho (CAPES/PNPD/UFCG/CTRN/PPGRN 201713705-5). Finally, we thank anonymous reviewers for their valuable suggestions.

\section{References}

Alcaldía de Turbaco-Bolívar. 2012. Jardín Botánico Guillermo Piñeres // Available at http://www.turbaco-bolivar.gov.co. Accessed on 1 January 2016.

Arcangeli A. 1930. Contributo alla conoscenza del "micorgenton" di Costa Rica. I. Isopodi terrestri // Bollettino del Laboratorio di Zoologia Generale e Agraria della R. Scuola Duperiore d'Agricoltura in Portici. Vol.25. P.1-29. 

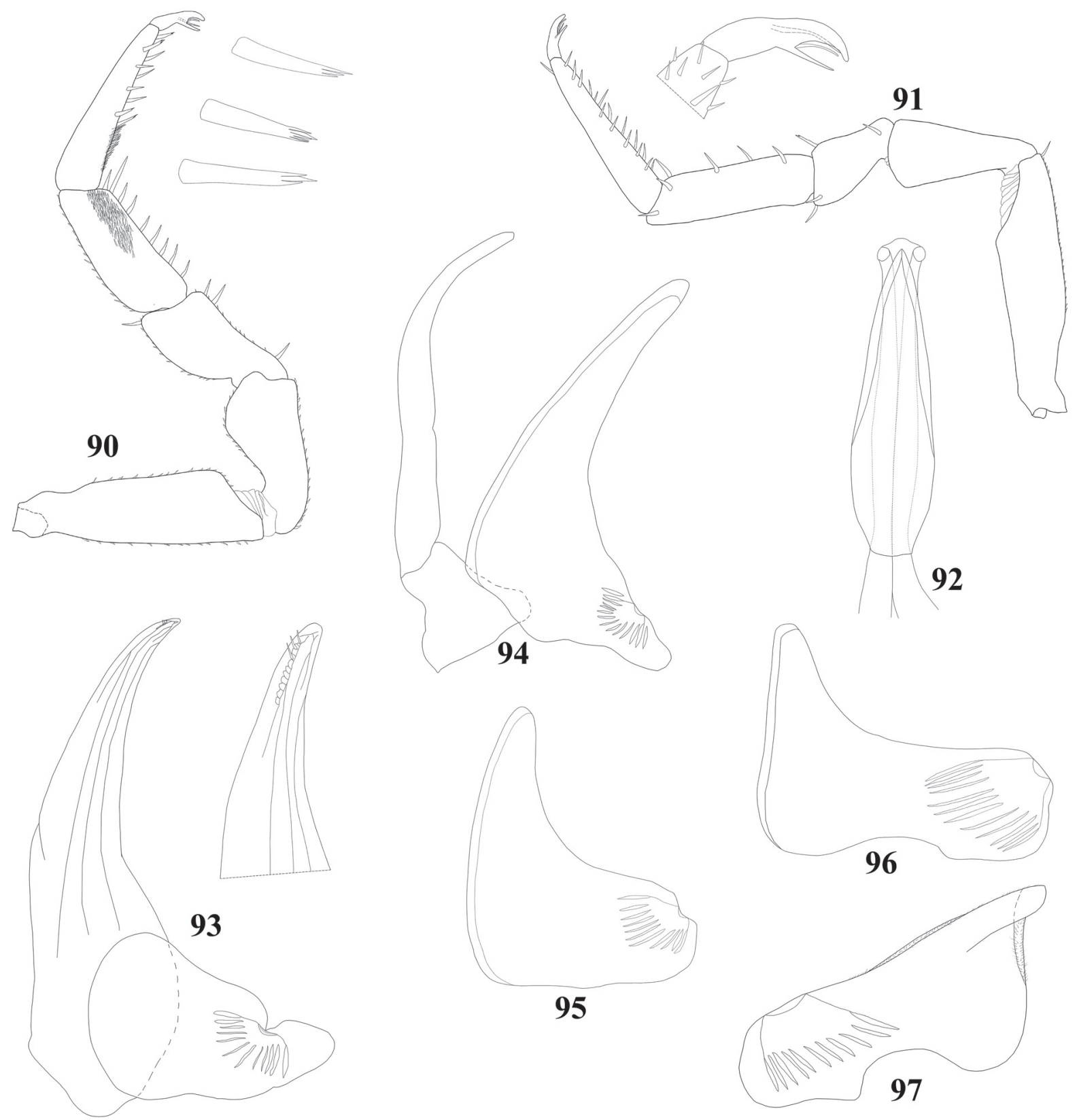

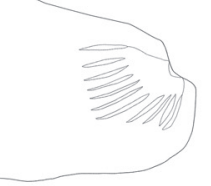

95

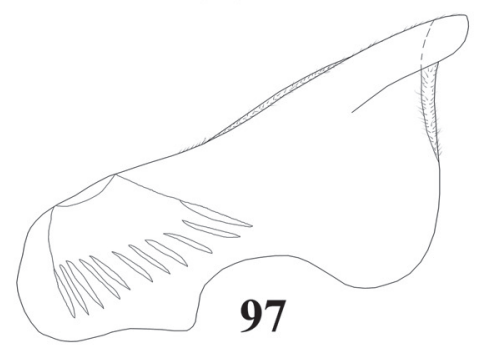

Figs 90-97. Venezillo gigas (Miers, 1877), male: 90 — pereopod 1;91 — pereopod 7; 92 — genital papilla; 93 — pleopod 1;94 pleopod 2; 95 — pleopod 3 exopod; 96 — pleopod 4 exopod; 97 — pleopod 5 exopod.

Рис. 90-97. Venezillo gigas (Miers, 1877), самец: 90 - переопод 1; 91 - переопод 7; 92 - генитальная папилла; 93 - плеопод 1; 94 — плеопод 2; 95 - экзопод плеопода 3; 96 - экзопод плеопода 4; 97 — экзопод плеопода 5.

Arcangeli A. 1957. I generi Diploexochus, Venezillo, Paramardillo [sic] (crostacei isopodi terrestri) // Bollettino dell'Istituto e Museo di Zoologia dell'Università di Torino. Vol.5. P.101142 .

Banda-R K., Delgado-Salinas A., Dexter K.G., Linares-Palomino R., Oliveira-Filho A., Prado D., Pullan M., Quintana C., Riina R., Rodríguez-M G.M., Weintritt J., Acevedo-Rodríguez P., Adarve J., Álvarez E., Aranguren-B A., Arteaga J.C., Aymard G., Castaño A., Ceballos-Mago N., Cogollo A., Cuadros H., Delgado F., Devia W., Dueñas H., Fajardo L., Fernández A., Fernández M.A., Franklin J., Freid E.H., Galetti L.A., Gonto R., González-M R., Graveson R., Helmer E.H., Idárraga A.,
López R., Marcano-Vega H., Martínez O.G., Maturo H.M., McDonald M., McLaren K., Melo O., Mijares F., Mogni V., Molina D., Moreno N.P., Nassar J.M., Neves D.M., Oakley L.J., Oatham M., Olvera-Luna A.R., Pezzini F.F., Dominguez O.J.R., Ríos M.E., Rivera O., Rodríguez N., Rojas A., Särkinen T., Sánchez R., Smith M., Vargas C., Villanueva B., Pennington R.T. 2016. Plant diversity patterns in neotropical dry forests and their conservation implications // Science. Vol.353. No.6306. P.1383-1387.

Boyko C.B., Bruce N.L., Merrin K.L., Ota Y., Poore G.C.B., Taiti S., Schotte M., Wilson G.D.F. 2008a. [Trichorhina BuddeLund, 1908] World marine, freshwater and terrestrial isopod 
crustaceans database; [cited 2018 Jul 17]. Available from: http://www.marinespecies.org/aphia.php? $\mathrm{p}=$ taxdetails\&id= 249422

Boyko C.B., Bruce N.L., Merrin K.L., Ota Y., Poore G.C.B., Taiti S., Schotte M., Wilson G.D.F. 2008b. [Ctenorillo Verhoeff, 1942]. World marine, freshwater and terrestrial isopod crustaceans database; [cited 2018 Jul 17]. Available from: http:/ www.marinespecies.org/aphia.php? $\mathrm{p}=$ taxdetails\&id $=248659$

Boyko C.B., Bruce N.L., Merrin K.L., Ota Y., Poore G.C.B., Tait S., Schotte M., Wilson G.D.F. 2008c. [Venezillo Verhoeff, 1928] World Marine, freshwater and terrestrial isopod crustaceans database; [cited 2018 Jul 17]. Available from: http:// www.marinespecies.org/aphia.php? $\mathrm{p}=$ taxdetails \&id=249464

Brandt J.F. 1831. [Isopoda. Gleichfüßler] // Brandt J.F., Ratzeburg J.C.T. (Hrsg.). Medizinische Zoologie oder getreue Darstellung und Beschreibung der Thiere die in der Arzneimittellehre in Betracht kommen, in systematischer Folge herausgegeben. Bd.2. Isopoda. Berlin: bei den Verfassern und in Commission bei A. Hirschwald; gedruckt in der Druckerei der Königlichen Academie der Wissenschaften und bei Trowitzsch und Sohn, 1829-1833. S.70-84, P1. 12-13.

Brandt J.F. 1833. Conspectus Monographiae Crustaceorum Oniscodorum Latreillii // Bull/ Soc. Nat. Moscou. Vol.6. P.171193.

Budde-Lund G. 1879. Prospectus generum specierumque Crustaceorum Isopodum Terrestrium // Copenhaguen: Imprimerie de Jørgensen \& Knudtzon. P.10.

Budde-Lund G. 1885. [Crustacea Isopoda terrestria per familia et genera et species descripta]. Copenhagen: Nielsen \& Lydiche. $319 \mathrm{p}$.

Budde-Lund G. 1893. Landisopoder fra Venezuela, indsamlede af Dr. Fr. Meinert // Entomologiske Meddelelser. Vol.4. P.111129.

Budde-Lund G. 1904. [Spherilloninae. Armadillo] // Hagerup H. (ed.). A revision of Crustacea Isopoda terrestria, with additions and illustrations. Copenhagen: H. Hagerup. P.33-144.

Budde-Lund G. 1908. [Isopoda von Madagaskar und Ostafrika mit Diagnosen verwandter Arten] // Voeltzkow A. (Hrsg.). Reise in Ostafrika in den Jahren 1903-1905. Bd.2. Stuttgart: Wissenschaftliche Ergebnisse. S.265-308.

Campos-Filho I.S., Araujo P.B., Bichuette M.E., Trajano E., Taiti S. 2014. Terrestrial isopods (Crustacea: Isopoda: Oniscidea) from Brazilian caves // Zoological Journal of the Linnean Society. Vol.172. P.360-425.

Campos-Filho I.S., Montesanto G., Araujo P.B., Taiti S. 2017. New species and new records of terrestrial isopods (Crustacea, Isopoda, Oniscidea) from Brazil // Iheringia, Série Zoologia. Vol.107. P.e2017034.

Carpio-Díaz Y.M., López-Orozco C.M., Herrera-Medina Y., Navas G.R., Bermúdez A. 2016. Primer registro de Tylos niveus y nuevo reporte de Porcellionides pruinosus (Oniscidea: Tylidae y Porcellionidae) para Colombia // Revista de la Academia Colombiana de Ciencias Exactas Físicas y Naturales. Vol.40. No.156. P.4233-4437.

Coleman C.O. 2006. Substituting time-consuming pencil drawings in arthropod taxonomy using stacks of digital photographs // Zootaxa. Vol.1360. P.61-68.

Dollfus A. 1893. Voyage de M.E. Simon au Venezuela (Decembre 1887 - April 1888). 25e mémoire. Isopodes terrestres // Annales de la Société Entomologique de France. Vol.62. P.339346, Pl. 9-10.

Dollfus A. 1896. On West Indian terrestrial isopod crustaceans // Proceedings of the Zoological Society of London. P.388-400.

Etter A., van Wyngaarden W. 2000. Patterns of landscape transformation in Colombia, with emphasis in the Andean region // AMBIO: A Journal of the Human Environment. Vol.29. No.7. P.432-439.

Grangeiro D.C., Christoferssen M.L. 2010. A new species of Androdeloscia (Isopoda: Philosciidae) from the Brazilian Amazon // Revista Noderstina de Biologia. Vol.19. No.2. P.77-93.

Kinahan J. 1857. Analysis of certain allied genera of terrestrial isopods; with description of a new genus, and a detailed list of the British species of Ligia, Philougria, Philoscia, Porcellio, Oniscus and Armadillium [sic] // Natural History Review. Vol.4. P.258-282.

Lamoreux J.F., Morrison J.C., Ricketts T.H., Olson D.M., Dinerstein E., McKnight M.W., Shugat H.H. 2006. Global tests of biodiversity concordance and the importance of endemism // Nature. Vol.440. P.212-214.

Latreille A. 1802. Famille Seconde. Cloportides // Histoire naturelle, générale et particulière des crustacés et des insects. Tome III. Paris: L'Imprimeria de F. Dufart. P.42-43.

Leistikow A. 1999. Androdeloscia gen. n., a new genus of South American terrestrial isopods with description of 13 new species (Crustacea: Oniscidea: "Philosciidae") // Revue suisse de Zoologie. T.106. P.813-904.

Leistikow A. 2001a. A new species of terrestrial Isopoda from the Sierra Nevada de Santa Marta, Colombia (Crustacea: Oniscidea: Crinocheta) // Studies on Neotropical Fauna and Environment. Vol.36. P.151-158.

Leistikow A. 2001b. The genus Erophiloscia, Vandel, 1972 - its phylogeny and biogeography, with descriptions of three new species (Crustacea, Isopoda, Oniscidea) // Spixiana. Vol.24. No.1. P.29-51.

Leistikow A., Wägele J.W. 1999. Checklist of terrestrial isopods of the New World (Crustacea, Isopoda, Oniscidea) // Revista Brasileira de Zoologia. Vol.16. No.1. P.1-72.

Lemos de Castro A. 1964. Trichorhina heterophthalma nueva especie de isopodo terrestre cavernicola de Cuba // Poeyana. Vol.2a. P.1-7.

López-Orozco C.M., Bermúdez A., Navas G.R. 2014. Primer registro de Ligia baudiniana (Crustacea: Isopoda: Oniscidea) para el Caribe colombiano // Boletín de Investigaciones Marinas y Costeras. Vol.43. No.1. P.195-200.

López-Orozco C.M., Carpio-Díaz Y.M., Navas G.R., Campos-Filho I.S. 2016. A new species and first record of Androdeloscia (Oniscidea: Philosciidae) from Colombia // Studies on Neotropical Fauna and Environment. Vol.52. No.1. P.18-24.

López-Orozco C.M., Carpio-Díaz Y.M., Navas G.R., Campos-Filho I.S. 2017. A new species and first record of Pulmoniscus Leistikow, 2001 (Isopoda, Oniscidea, Philosciidae) from Colombia // Nauplius. Vol.25. e2017014.

Miers E.J. 1877. On a collection of Crustacea, Decapoda and Isopoda chiefly from South America, with description of new genera and species // Proceedings of the Zoological Society of London. P.653-679.

Milne-Edwards M. 1840. [Ordre des isopodes] // Milne-Edwards M. (ed.). Histoire Naturelle des Crustacés, comprenant l'anatomie, la physiologie et la classficiation de ces animaux // Paris: Librairie Encyclopédique de Roret. Tome Troisième. P.115-283.

Montesanto G. 2015. A fast GNU method to draw accurate scientific illustrations for taxonomy // ZooKeys. Vol.515. P.191206.

Montesanto G. 2016. Drawing setae: a GNU way for digital scientific illustrations // Nauplius. Vol.24. e2016017.

Moore H. 1901. Report on Porto Rican Isopoda // Bulletin of the United States Fish Commission. Vol.20. P.163-176.

Morrone J.J. 2014. Biogeographical regionalisation of the Neotropical region // Zootaxa. Vol.3782. No.1. P.1-110.

Myers N., Mittermeier R.A., Mittermeier C.G., Fonseca G.A.B., Kent J. 2000. Biodiversity hotspots for conservation priorities // Nature. Vol.403. P.853-858.

Olson D.M., Dinerstein E., Wikramanayake E.D., Burgess N.D., Powell G.V.N., Underwood E.C., D’Amico J.A., Itoua I., Strand H.E., Morrison J.C., Loucks C.J., Allnutt T.F., Ricketts T.H., Kura Y., Lamoreux J.F., Wettengel W.W., Hedao P., Kassem K.R. 2001. Terrestrial ecoregions of the world: a new map of life on Earth // BioScience Vol.51. No.11. P.933-938.

Pearse A. 1915. An account of the Crustacea collected by the Walker Expedition to Santa Marta, Colombia // Proceedings of the United States national Museum. Vol.49. P.531-556.

Pennington R.T., Lewis G.P., Ratter J.A. 2006. [An overview of the plant diversity, biogeography and conservation of neotropical savannas and seasonally dry forests] // Pennington R.T., 
Lewis G.P., Ratter J.A. (eds.). Neotropical savannas and dry forests: diversity, biogeography, and conservation. Systematics Association Special Volumes, No.69. London: Taylor \& Francis. P.1-29.

Preciado A.F., Martínez J.W. 2014. Estudio de isópodos terrestres (Crustacea: Isopoda: Oniscidea) en tres localidades de Boyacá Colombia // Revista de Ciencias Agrícolas. Vol.31. No.2. P.14 23.

Richardson H. 1901. Key to the isopods of the Atlantic coast of North America, with descriptions of new and little-known species // Proceedings of the United States National Museum. Vol.23. P.493-579.

Richardson H. 1905. A monograph on the isopods of North America // Bulletin of the United States National Museum. Vol.54. 727 p. (Oniscidea. P.583-717).

Richardson H. 1912. Terrestrial isopods of Colombia // Mémoires de la Société des Sciences Naturelles de Neuchâtel. Vol.5. P.29-32.

Schmalfuss H. 2003. World catalog of terrestrial isopods (Isopoda: Oniscidea) // Stuttgarter Beiträge zur Naturkunde. Serie A. Bd.654. S.1-341.

Schmalfuss H., Ferrara F. 1983. Terrestrial isopods from West Africa, Part 3: family Armadillidae Verhoeff, 1917 // Monitore Zoologico Italiano, Nuova Serie. Suppl.18. P.111-157.

Schmidt C. 2002. Contribution to the phylogenetic system of the Crinocheta (Crustacea, Isopoda). Part 1 (Olibrinidae to Scyphacidae s. str.) // Mitteilungen aus dem Museum für Naturkunde in Berlin. Bd.78. P.275-352.

Schmidt C. 2003. Contribution to the phylogenetic system of the Crinocheta (Crustacea, Isopoda). Part 2 (Oniscoidea to Armadillidiidae) // Mitteilungen aus dem Museum für Naturkunde in Berlin. Bd.79. P.3-179.

Schmidt C. 2007. Revision of the Neotropical Scleropactidae (Crustacea: Oniscidea) // Zoological Journal of the Linnean Society. Vol.151. P.1-339.

Schmidt C., Leistikow A. 2005. Review of the genus Androdeloscia Leistikow, with description of four new species (Crustacea Isopoda: Oniscidea) // Entomologische Abhandlungen. Bd.62. H.2. P.17-163.

Schultz G.A. 1995. Terrestrial isopod crustaceans (Oniscidea) from Paraguay with definition of a new family // Revue suisse de Zoologie. T.102. Fasc.2. P.387-424.

Sfenthourakis S., Taiti S. 2015. Patterns of taxonomic diversity among terrestrial isopods // ZooKeys. Vol.515. P.13-25.

Souza-Kury L.A. 1993. Notes on Trichorhina I. Two new species from Northeastern Brazil (Isopoda, Oniscidea, Platyarthridae) // Revue suisse de Zoologie. T.100. Fasc.1. P.197-201.

Souza-Kury L.A. 1997. Two New Species of Trichorhina from Brazilian Amazonia (Isopoda, Oniscidea, Platyarthridae) // Crustaceana. Vol.70. No.2. P.180-190.

Souza L.A., Araújo J.P., Campos-Filho I.S. 2011. The genus Trichorhina Budde-Lund in Brazil, with description of seven new species (Isopoda, Oniscidea, Platyarthridae) // Iheringia, Série Zoologia. Vol.101. No.3. P.239-261.

Taiti S. 2018. A new termitophilous species of Armadillidae from South Africa (Isopoda: Oniscidea) // Onychium. Vol.14. P.915 .

Taiti S., Allspach A., Ferrara F. 1995. A new family placement for the genus Colomboscia Vandel, 1972, with description of a new species (Crustacea, Oniscidea, Scleropactidae) // Studies on Neotropical Fauna and Environment. Vol.30. No.2. P.91100 .

Taiti S., Montesanto G., Vargas J.A. 2018. Terrestrial Isopoda (Crustacea, Oniscidea) from the coasts of Costa Rica, with descriptions of three new species // Revista Biologia Tropical. Vol.66. Suppl.1. P.S187-S210.

Taiti S., Paoli P., Ferrara F. 1998. Morphology, biogeography, and ecology of the family Armadillidae (Crustacea, Oniscidea) // Israel Journal of Zoology. Vol.44. P.291-301.

Taiti S., Wynne J. 2015. The terrestrial Isopoda (Crustacea, Oniscidea) of Rapa Nui (Easter Island), with descriptions of two new species // ZooKeys. Vol.515. P.27-49.

Van Name W.G. 1920. Isopods collected by the American Museum Congo Expedition // Bulletin of the American Museum of Natural History. Vol.43. P.41-108.

Van Name W.G. 1936. The American land and freshwater isopod Crustacea // Bulletin of the American Museum of Natural History. Vol.71. P.1-535.

Vandel A. 1952. Étude des isopodes terrestres récoltés au Vénézuela par le Dr. G. Marcuzzi // Memorie del Museo Cívico di Storia Naturale di Verona. Vol.3. P.59-203.

Vandel A. 1962. [Isopodes terrestres (Deuxième Partie)] // Fédération Française des Sociétes de Sciences Naturelles (ed.). Faune de France. Vol.66. Paris: P. Lechevalier. P.417-931.

Vandel A. 1972. Les isopodes terrestres de la Colombie // Studies on the Neotropical Fauna. Vol.7. P.147-172.

Verhoeff KW. 1908. Über Isopoden (15. Isopoden-Aufsatz) // Archiv Biontologie. Bd.2. S.335-387.

Verhoeff K.W. 1928. Über einige Isopoden der Zoologischen Staatssammlung in München // Zoologischer Anzeiger. Bd.76. S.25-36, 113-123.

Verhoeff KW. 1938. Weltstellung der Isopoda terrestria, neue Familien derselben und neues System // Zoologische Jahrbücher, Abteilung für Systematik, Ökologie und Geographie der Tiere. Bd.71. S.253-264.

Verhoeff K.W. 1942. Äthiopische Isopoda terrestria der Hamburger Zoologischen Museums // Zoologischer Anzeiger. Bd.140. S.1-163.

Verhoeff K.W. 1949. Über Land-Isopoden aus der Turkei. III // Istanbul Universitesi Fen Fakultesi Mecmuasi, Serý B. Vol.14. S.21-48.

Responsible editor K.G. Mikhailov 